\title{
Employing Live Microbes for Vaccine Delivery
}

\author{
Holger Loessner, Astrid Schwantes, Matthias Hamdorf, \\ Uliana Komor, Sara Leschner, and Siegfried Weiss
}

\begin{abstract}
The employment of live attenuated vaccines has a long-standing record in human and veterinary medicine. Most of the vaccines in current use were empirically developed during the last century. Today, due to the great advances in fields such as immunology and bioengineering, the rational development of live attenuated vaccines becomes increasingly feasible. Moreover, live vaccines can be used as carrier systems for heterologous antigens or therapeutic factors. In each case, the development of a recombinant live attenuated vaccine is a complex task where properties such as targeting specificity, antigen synthesis, antigen release, and safety aspects have to be integrated. A range of such recombinant vaccine candidates have successfully been tested in the clinics, but very few have been approved so far. In many cases, further optimization of such vaccines is necessary with regard to their efficacy and safety profiles. In the present chapter, we focus on current strategies which are employed for the development of new and the optimization of first generation recombinant live vaccines based on bacteria and viruses.
\end{abstract}

\subsection{Introduction}

Vaccination with live attenuated pathogenic viruses has a long tradition, although few people are aware of this. Already in the fifth century AD, variolation, the vaccination against smallpox virus with material from pustules of infected people, was practiced in China and later in India as well as in Japan and Europe (Mazumdar 2003). The material was applied intradermally or nasally. At a pending smallpox

\footnotetext{
S. Weiss $(\bowtie)$

Molecular Immunology, Helmholtz Centre for Infection Research, Inhoffenstr. 7,

38124 Braunschweig, Germany

e-mail: siw@helmholtz-hzi.de
} 
epidemic, even the grandchildren of George I, king of England, were variolated after rudimentary safety and efficacy trials using death-sentenced prisoners and orphans for testing. Although highly protective, variolation never reached general compliance in the Western world partly because a certain death toll had to be paid using this method. It was not before the groundbreaking experiment by Edward Jenner in 1796 that vaccination was generally accepted. Jenner prevented smallpox disease in a 13-year-old boy by preinoculation with cowpox virus and established convincingly the principle of immunization by the use of active agents, at this time without knowledge about the nature of the immunogen or the immune system. Following the discovery of pathogenic bacteria, Louis Pasteur pioneered the development of several vaccines. In 1879, he generated the first live attenuated bacterial vaccine by extended culture of fowl cholera bacteria, which could be applied to chicken without causing disease but preventing them from infection with a virulent strain (Pasteur 1880). This discovery marks the starting point for the development of live attenuated vaccines (LAV). Within the next 20 years at the end of the nineteenth century, a number of further vaccines quickly appeared, for example, anthrax and rabies vaccines developed by Pasteur or human vaccines against typhoid fever, cholera, and plague (Makela 2000). Since then, many LAV for human and animal use were developed until today, including live attenuated bacteria, fungi, parasites, and viruses. Such vaccines continue to have a tremendous impact in the prevention of infectious diseases despite a number of other vaccine classes have been introduced over time. This reflects unique characteristics of LAV, which are unmet by other vaccines thus far with respect to the induction of protective immune responses against specific pathogens (Table 5.1).

One of the hallmarks of LAV is that they efficiently target immune inductive sites during their limited infection cycle in the host. In contrast to the majority of other currently used vaccines, which preferentially induce antibody-mediated immune protection, LAV are capable of stimulating cellular immunity as well. However, potential risks such as virulence reversion or side effects particularly in immunocompromised individuals led to the replacement of some of the successful LAV in the past and raised continuously standards for approval of new live

Table 5.1 Pros and cons of current LAV

\begin{tabular}{ll}
\hline Pros & Cons \\
\hline Simulation of natural infection course & Risk of reversion to virulence \\
\hline Induction of cellular and antibody responses & Risk for immunocompromised individuals \\
\hline Induction of mucosal and systemic immunity & Risk of environmental release and spreading \\
\hline Mucosal administration routes & Reactogenicity \\
\hline High efficacy, single or few doses required & High costs during development \\
\hline Long-lasting immunity & Short shelf-life \\
\hline No adjuvant required & Regulatory hurdles \\
\hline No preservative required & Public resistance to genetically modified LAV \\
\hline Low production cost & \\
Easy transport and storage & \\
\hline
\end{tabular}


vaccines especially for human use (Table 5.1). For animals, benefit risk assessments of LAV often have a more positive outcome. The comparatively small number of approved human LAV is opposed to a relatively large number of veterinary LAV against a whole array of pathogens today.

The advent of recombinant DNA technology opened up the possibility of targeted modification of microbes. This paved the way for rational attenuation of LAV, rendering them nonpathogenic even in the absence of a functional host immune system and inert to changes in diet, commensal flora, or other individual traits. In addition, the use of LAV as delivery systems for foreign antigens derived from other pathogens or therapeutic molecules is now possible. Meanwhile, a considerable number of such recombinant LAV advanced into clinical testing or even have obtained marketing authorization. Notably, most approved recombinant LAV thus far are veterinary vaccines (Meeusen et al. 2007). However, the rapidly expanding knowledge about host-microbe interactions and recent technological advances, such as genome sequencing, global expression analysis techniques, as well as high end gene synthesis, will open up completely new ways to rationally design LAV as such or for recombinant vaccine delivery. Eventually, it will be possible to develop a new generation of LAV tailored for specific applications with an excellent safety and efficacy profile. Thus, harnessing the potential of LAV to induce all arms of the immune system, these vaccines probably will provide new options in the fight against major threads to human and animal health. Depending on the vector system of choice, "vaccine cargo" of different nature, size, and amount can be delivered. Whereas viral vaccine vectors in most cases will carry the genetic information of foreign antigens in order to mediate their expression in the host cells, other microbial vector systems offer more flexibility with respect to delivery and release of foreign antigens. Such delivery systems have been designed either to directly produce antigenic peptides or to deliver antigen-encoding nucleic acids to host cells.

\subsection{Bacterial LAV and Their Use for Vaccine Delivery}

\subsubsection{Bacterial LAV in Use Today and Novel Attenuation Strategies}

The majority of pathogenic bacteria either colonize or transit mucosal compartments during infection. In order to prevent bacterial infection and spreading of disease, the induction of mucosal immune responses is of particular importance. Bacterial LAV are regarded as prototype mucosal vaccines capable to induce mucosal as well as systemic immune responses (Dietrich et al. 2003; Kochi et al. 2003). In addition, mucosal vaccines often simplify administration, thereby enhancing safety and reducing costs of vaccination. Originally, most bacterial LAV were empirically derived from pathogenic isolates. Undirected methods such as passaging or chemical or physical mutagenesis were employed in order to reduce virulence of such strains yet retain their ability to transiently colonize host tissues and induce protective immunity. Such methods were stepwise replaced since the 1980s 
by directed mutagenesis. Currently, only three bacterial LAV are licensed for human use, namely, Bacillus Calmette-Guerin (BCG), Salmonella enterica serovar Typhi (S. typhi) strain Ty21a, and Vibrio cholerae (V. cholerae) strain CVD 103-HgR. In contrast, a wide range of bacterial LAV are utilized in veterinary medicine.

In case of the parenteral tuberculosis (TB) vaccine, BCG was passaged in culture medium for more than a decade and gave rise to the attenuated variant of the original Mycobacterium bovis isolate in 1919 (Calmette et al. 1927). Since then, BCG has been administered to about four billion people being therefore the most widely used bacterial LAV for human use thus far. However, BCG alone is unable to prevent pulmonary TB in adults. Only newborns can be temporarily protected this way, except HIV-infected babies (Mansoor et al. 2009). In order to prevent a resurgence of TB due to reasons such as increasing occurrence of multidrugresistant Mycobacterium tuberculosis strains or the prevalence of HIV, new vaccines are urgently needed. Improved recombinant BCG alone or as part of prime-boost approaches constitutes an important route of TB vaccine development (Kaufmann et al. 2010). As a replacement of BCG, also M. tuberculosis-derived attenuated variants are tested (Gonzalo-Asensio et al. 2008). As veterinary vaccine, BCG has been used successfully against bovine TB (Buddle et al. 2006).

The human LAV against typhoid fever $S$. typhi Ty21a and cholera $V$. cholerae CVD 103-HgR are orally administered. The vaccine strain $S$. typhi Ty21a has been obtained in the 1970s by chemical mutagenesis with nitrosoguanidine (Germanier and Fürer 1975). Colonies were screened for their sensitivity to galactose due to a lack of the enzyme uridine diphosphate galactose epimerase ( $\mathrm{galE}$ ). The reasoning was that such bacteria would then be deficient of the polysaccharide coat and therefore rendered vulnerable to the immune system. Unintentionally, a number of additional attenuating mutations were introduced this way (Germanier and Fürer 1983).

About 10 years later, the cholera vaccine strain V. cholerae CVD 103-HgR was more rationally derived from the pathogenic isolate by genetic engineering (Levine and Kaper 1993). Gene $c t x A$ encoding the toxic A subunit of the cholera toxin was deleted causing sufficient strain attenuation while leaving the expression of the immunogenic B subunit unaffected. Furthermore, gene hlyA encoding hemolysin was disrupted by integration of a mercury resistance gene, which allows discrimination from wild-type strains.

In veterinary medicine, since decades, many LAV against bacterial diseases are in use, which were established in most cases by undirected mutagenesis. Most prominent examples are vaccines against salmonellosis for poultry, swine, and cattle. Various serovars of Salmonella enterica are causative agents of either enteritis or septicemia in animals. In turn, contaminated animal-derived food products are the main sources for human Salmonella infections (Barrow 2007). Attenuated Salmonella vaccine strains established by chemical mutagenesis have been introduced into veterinary practice in the 1970s and are often in use until today (Linde et al. 1974; Meyer et al. 1993). Directed attenuation by genetic engineering became feasible in the 1980s. A number of suitable gene targets were identified, 
belonging mainly to metabolic pathways, regulatory systems, or virulence determinants. Interference with synthesis of aromatic amino acids by deletion of gene aroA (encoding 5-enolpyruvyl shikimate-3-phosphate synthase) proved to be an excellent strategy for safe attenuation while retaining immunogenicity of a S. typhimurium strain (Hoiseth and Stocker 1981). This concept was subsequently transferred for attenuation to a number of other bacteria, such as Aeromonas salmonicida (Vaughan et al. 1993), Yersinia enterocolitica (Bowe et al. 1989), Pasteurella multocida (Homchampa et al. 1992), Escherichia coli (Fan et al. 2004), and Streptococcus equi (Jacobs et al. 2000), of which several strains were successfully commercialized as LAV for animal use. As a strategy to reduce the likelihood of virulence reversion, e.g., due to unwanted acquisition of complementing DNA sequences, attenuation of multiple genes was proposed. Mutations of genes aroA and aroD, both part of the same metabolic pathway, were introduced into vaccine strains of S. typhi (Chatfield et al. 1992b) and Shigella flexneri (Verma and Lindberg 1991).

A prerequisite for the use of animal vaccines is often the ability to differentiate $i$ nfected from vaccinated $a$ nimals (DIVA concept) (van Oirschot 2001). This can be achieved by deletion of an immunogenic antigen such that vaccinated animals are seronegative for it but not for other protective vaccine antigens. In the case of Actinobacillus pleuropneumoniae, the causative agent of porcine pleuropneumonia, sequential deletion of six genes gave rise to an appropriate attenuated candidate vaccine strain, which also complies to the DIVA concept (Maas et al. 2006).

However, the removal of virulence determinants often gives rise to strains, which fail to transiently colonize immune inductive sites and therefore do not induce potent immune responses. In accordance, the so-called strategy of regulated delayed attenuation was established recently in order to circumvent this problem (Curtiss III et al. 2009). Here, the vaccine strain is designed in a way that the invasive phenotype of the strain is retained during the initial phase of vaccination until immune inductive sites have been colonized. Subsequently, due to the lack of a particular substrate in vivo, the invasive phenotype of bacteria fades before acute disease is elicited. Proof of concept was established with mutant strains lacking either genes galE or pmi (phosphomannose isomerase) (Curtiss III et al. 2010). Such mutants are attenuated due to the lack of functional lipopolysaccharide (LPS). However, when grown in the presence of either galactose or mannose, respectively, these mutants synthesize LPS and are able to colonize host tissue upon oral administration. Since both sugars are not present in vivo, LPS synthesis is subsequently abrogated and bacteria rendered vulnerable to host defenses.

Finally, after successful establishment and clinical testing of a bacterial LAV, careful risk assessment is necessary prior to vaccine registration (Frey 2007). Despite safety concerns for the approval of genetically modified LAV at present, rationally engineered strains will probably gain acceptance in the future due to the high degree of molecular definition in addition to their superior performance. 


\subsubsection{Recombinant Bacterial LAV for Vaccine Delivery}

Bacterial LAV have a proven track record of efficacy in human and veterinary medicine. In addition, the understanding of LAV interaction with the host immune system has greatly advanced (Kaufmann 2007). This is an excellent basis for the development of a next generation of bacterial LAV. Existing vaccines will eventually be replaced by refined strains, in which, in addition to defined attenuation, a number of other features are rationally designed like modulated expression of immunogenic components (Fig. 5.1). Furthermore, recombinant DNA technology provides the possibility to program such strains at the same time as delivery system for foreign antigens, nucleic acid-based vaccines, or therapeutic molecules (Fig. 5.1). By now, a wide range of bacteria are explored for these purposes. In this case, distinct properties of bacterial species can be harnessed or diverted depending on the specific needs for the spectrum of medical applications (Fig. 5.2). Nonpathogenic bacteria such as food-derived or commensal lactic acid bacteria are attractive for the delivery of vaccines and therapeutics especially via the mucosa because they are considered of being generally safe (Wells and Mercenier 2008). In contrast to invasive attenuated bacteria, they do not actively enter and replicate inside host cells. Therefore, release of heterologous antigens from such bacteria occurs primarily in the extracellular space (Fig. 5.2a). In accordance, they mainly stimulate induction of antibody responses in several vaccination models. However, extracellular LAV can also be engineered to directly inject heterologous antigens into the

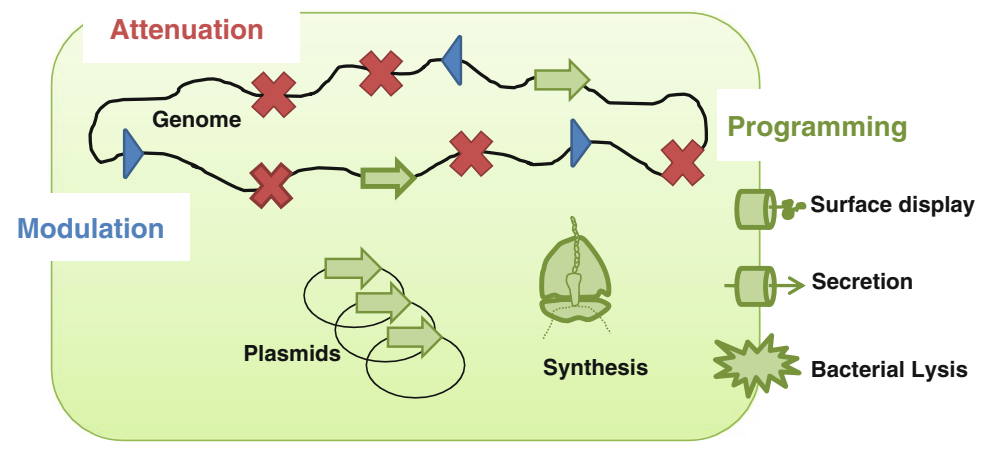

Fig. 5.1 Next-generation bacterial LAV for vaccine delivery. The development of a new bacterial LAV for the delivery of a specific vaccine is a complex and individual process for each application. First, a suitable bacterial carrier strain has to be selected and to be attenuated in a defined manner (red symbols). In order to potentiate vector-directed immune responses (if intended) or to provide optimal adjuvant activity components of the strain can be modulated (blue symbols). Examples for modulation could be overexpression of immunogenic surface proteins or the removal of anti-apoptotic genes from the carrier strain in order to strengthen cross-priming. The synthesis and delivery of heterologous protein and/or nucleic acids requires precise programming of the vaccine strain (green symbols). Expression cassettes are either located on plasmids or integrated into the chromosome. Expression determinants and coding sequences can be optimized. Finally, release and transfer of vaccine components from bacteria to the immune cells can either be achieved by secretion or bacterial disintegration 
a

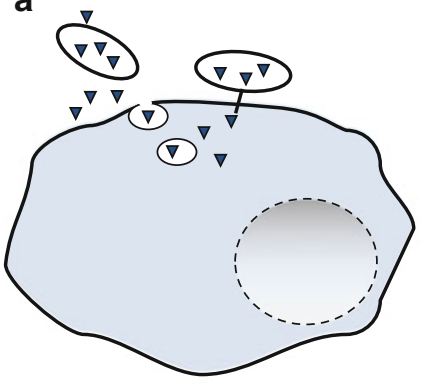

b

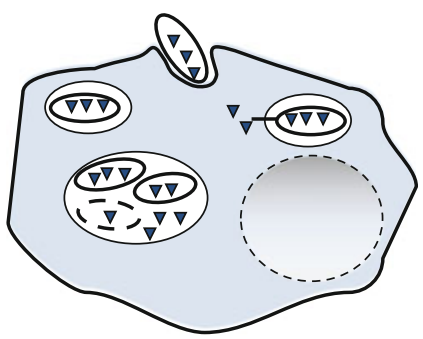

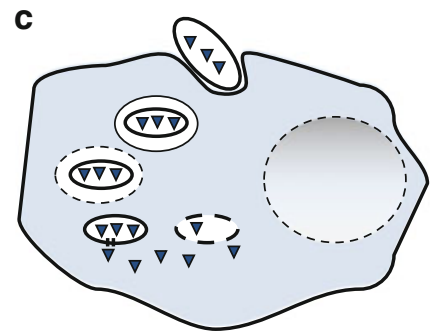

Fig. 5.2 Delivery of heterologous antigens or nucleic acids by bacterial LAV. (a) Heterologous antigen delivery by extracellular bacteria. Antigens can either be released outside the host cell or delivered into the host cell cytoplasm, e.g., by a type III secretion system. (b) Delivery of heterologous antigens from bacteria which are restricted to an intracellular vacuole, e.g., Salmonella. Antigens can either be targeted to the vacuole or to the cytosol. (c) Bacteria capable of vacuolar escape can deliver heterologous antigen directly to the cytoplasm of the host cell upon degradation or by secretion

host cell cytosol in order to induce cytotoxic T-cell responses (Fig. 5.2a). This was first demonstrated by employing an extracellular Yersinia pseudotuberculosis carrier strain mediating the cytosolic delivery of listeriolysin O (LLO), a protective antigen of Listeria monocytogenes (L. monocytogenes), via its type III secretion apparatus (Russmann et al. 2003). More often, recombinant LAV have been derived from bacteria capable of invading host cells, such as Salmonella spp., $L$. monocytogenes, or Shigella flexneri (Curtiss III 2002; Kotton and Hohmann 2004). In case of Salmonella, subsequent to cellular invasion, bacteria reside naturally inside a phagosome. They subvert this compartment into a protected niche for proliferation. Presentation of heterologous antigens expressed by attenuated Salmonella that undergo disintegration in this compartment is therefore restricted mainly to the MHC-II pathway leading to CD4 T-cell activation (Fig. 5.2b). In contrast, L. monocytogenes or Shigella flexneri escape the vacuolar compartment soon after cellular uptake and replicate inside the cytosol. Thus, upon carrier disintegration, vaccine cargo can be directly released into the cytoplasm (Fig. 5.2c). This allows presentation of heterologous antigens via MHC-I molecules to CD8 T-cells. However, the great advances in understanding the molecular mechanisms, which lead to a particular bacterial function such as host cell invasion, 
intracellular residence, etc., will allow more and more to interchange the underlying molecular systems between bacterial species in order to tailor bacterial LAV precisely for specific applications.

In the present chapter, we will focus especially on Salmonella vaccine vectors in order to exemplify major improvement strategies for the development of bacterial LAV in general. Salmonella LAV constitute promising vectors for heterologous antigens because after oral administration, they are able to invade and colonize mucosal and systemic immune inductive compartments at the same time. Thus, long-lasting humoral and cellular immune responses have been induced against a wide spectrum of antigens delivered by Salmonella LAV (Galen et al. 2009; Kwon et al. 2007; Moreno et al. 2010). In addition to the selection of a suitable vector strain which meets the balance between immunogenicity and safety (as discussed before), the strategy of heterologous antigen synthesis and delivery has to be carefully considered for each antigen and the anticipated immune response (Galen and Levine 2001; Kotton and Hohmann 2004). Definition and implementation of such a strategy can be a very challenging and complex process.

\subsubsection{Level and Timing of Antigen Expression}

For the induction of strong antibody responses, high amounts of antigen are required in most cases, whereas for cellular responses, moderate antigen delivery may suffice. Therefore, strong constitutive promoters were used initially for the expression of heterologous antigens by bacterial LAV (Brown et al. 1987). However, even when achieved at all, such high-level expression of antigen often constitutes a serious burden for the vaccine strain, which reduces its ability of tissue colonization and to induce immune responses. As a solution to this problem, the use of in vivo inducible (IVI) promoters was proposed which are derived from genes that become activated under conditions encountered at certain stages of the colonization course. At first, the nitrite reductase promoter $\left(\mathrm{P}_{\text {nirB }}\right)$ of E. coli was employed which is induced by intestinal hypoxia (Chatfield et al. 1992a). Subsequently, a number of additional IVI promoters were tested for the expression of heterologous antigens (Hohmann et al. 1995; Stratford et al. 2005; Valdivia and Falkow 1997). Each individual promoter differs in the timing and level of antigen expression and consequently influences the antigen-specific immune induction (Bumann 2001). An alternative approach was developed in the Curtiss lab which was named "regulated delayed synthesis of antigens" (Xin et al. 2008). Here, antigen production is retarded due to the arabinose-dependent expression of a repressor protein driven by the $\mathrm{P}_{\mathrm{BAD}}$ promoter in vitro (Guzman et al. 1995). Upon vaccine administration, the repressor expression ceases due to the lack of arabinose in the gastrointestinal tract of the mice, thus relieving the repressor blockade of the antigen expression cassette. For both strategies, the use of IVI promoters or the employment of a regulated delayed synthesis system, the time point of antigen synthesis and the expression level is fixed and cannot be tuned during vaccination. We therefore have recently tested the suitability of substrate-inducible promoters for the deliberate onset and adjustment of reporter gene expression by bacterial LAV in vivo (Loessner et al. 2007, 2009). Such promoters constitute a new option for inducible 
antigen expression in a controlled manner in vivo, a concept that was termed "in vivo remote control" (IVRC). However, since for optimal induction of immune responses, such as Th1-type responses, continuous antigen expression is necessary (Griffin and McSorley 2011), prolonged administration of inducer substrate would probably be required when IVRC promoters are employed.

\subsubsection{Expression Cassette}

Plasmids harboring expression cassettes are often used for conversion of vaccine strains into delivery vehicles for heterologous antigens. The main advantage of plasmids is that they can be easily manipulated in E. coli and subsequently transferred into vaccine strains. In addition, multicopy plasmids mediate elevated levels of antigen synthesis in comparison to single-copy chromosomal expression cassettes. However, episomal plasmid replication constitutes a metabolic burden for bacteria, thus further attenuating the vaccine strain (Covone et al. 1998). Moreover, plasmid maintenance is often achieved by antibiotic selection in vitro. In the absence of this selective pressure in vivo, plasmids are often lost from the proliferating bacteria. In order to ensure stability of the plasmid transformants without the need of antibiotic selection, so-called balanced lethal systems have been established (Curtiss III et al. 1990). Such systems rely on host strains with a chromosomal deletion of an essential metabolic gene. The defect of this gene is complemented on the expression plasmid, therefore ensuring stable plasmid propagation. An alternative approach is the use of so-called addiction systems for plasmid stabilization (Galen et al. 1999).

In contrast, integration of expression cassettes into the bacterial genome ensures stable propagation. However, genomic integration of single expression cassettes often does not mediate synthesis of sufficient antigen levels. A solution to this problem would be multiple integrations of the same expression cassette. However, in recombination competent vaccine strains such repetitions of homologous sequences are often instable due to undesired recombination events. In accordance, removal of recombinases from vaccine strains is an important advancement for the stabilization of such repetitive chromosomal integrations and also plasmid DNA (Zhang et al. 2011).

Nowadays, gene synthesis is rapidly replacing cloning procedures for the establishment of antigen expression cassettes (Kindsmuller and Wagner 2011). Thus, the fine tuning of promoter elements or the optimization of coding sequences, e.g., the adjustment of codon usage, has been accelerated tremendously.

\subsubsection{Antigen Release}

Several properties of the vaccine strain, such as cellular tropism, bacterial virulence mechanisms, and type of attenuation, predetermine the time point and location of antigen delivery (Fig. 5.2) (Cheminay and Hensel 2008; Loessner et al. 2008). Since requirements for protective immune responses against pathogens differ, targeting of heterologous antigens into different presentation pathways is necessary. Thus, the choice of the right attenuated vaccine strain is important to accomplish such efficient targeting. Heterologous antigens synthesized by bacterial LAV 
have to be released from the bacteria in order to be recognized by immune cells. Gram-negative bacteria lacking gene asd encoding the aspartate-semialdehyde dehydrogenase undergo cell death in environments lacking diaminopimelic acid (DAP). Since DAP is absent in the gastrointestinal tract, orally applied bacteria deficient of asd quickly lyse in vivo (Curtiss III 1978). During DAP-less death, the bacterial cell wall spontaneously bursts, and cytoplasmic cellular contents such as protein and nucleic acids are efficiently released (Loessner et al. 2006). In contrast, other lethal attenuations, such as deficiency of thyA (thymidylate synthase) in thymine or thymidine-deprived environments, do not cause rupture of the bacterial cell, and therefore, no immediate release of cytoplasmic material occurs. Hence, subsequent slow degradation of bacterial carcasses may prevent release and presentation of heterologous antigen. As alternative to strain attenuation, inducible lysis systems have been developed which mediate efficient release of cytoplasmic antigen or nucleic acid from ruptured bacterial cells. For instance, bacteriophage lysis determinants have been employed for this purpose (Jain and Mekalanos 2000). The use of lysis protein E derived from phage phiX174 has already been employed for some time to prepare bacterial cell envelopes devoid of cytoplasmic content to be used for vaccination, so-called bacterial ghosts (Jalava et al. 2003). The employment of such lysis determinants for the release of heterologous antigens from a bacterial vector strain necessitates its tightly regulated inducible expression in vivo. This was achieved by linking lysis gene $E$ to the arabinose-inducible $\mathrm{P}_{\mathrm{BAD}}$ promoter, suitable for IVRC (see above) (Loessner et al. 2007), or more recently to quorum sensing or iron-regulated promoters (Guan et al. 2011; Silva et al. 2010). Similar to DAP-less death, lysis protein E causes rupture of bacterial cells by interference with cell wall synthesis (Bernhardt et al. 2000).

Another lysis strategy was established by the Curtiss lab, termed "regulated delayed lysis system" (Kong et al. 2008). In this work, a Salmonella double mutant strain was constructed with chromosomal deletions of two genes involved in cell wall biosynthesis, asd and murA. Plasmid-encoded complementing genes are linked to the arabinose-inducible $\mathrm{P}_{\mathrm{BAD}}$ promoter which was kept active by the presence of arabinose during culture. Upon oral vaccine administration, expression of both genes ceases due to absence of arabinose in vivo and bacteria disintegrate. Thus, this system confers attenuation and mediates antigen release at the same time.

Whereas cytoplasmic antigens are released at once from bacteria undergoing lysis, a viable bacterial carrier can be engineered to release antigen continuously by the use of a suitable secretion system. A variety of one-component or multicomponent secretion systems have been employed for this task. As single-component systems, so-called autotransporters, such as E. coli AIDA-I (Maurer et al. 1997), are suitable for translocation of passenger antigens across the gram-negative cell envelope. Stable display of antigens on the surface of a Salmonella vaccine strain via the E. coli AIDA-I efficiently induced cellular immune reactions (Kramer et al. 2003).

Similarly, the E. coli alpha-hemolysin (HlyA) secretion apparatus, belonging to the group of type I secretion systems, is fully active in Salmonella vaccine strains and has successfully been used for the delivery of a number of antigens 
(Gentschev et al. 2002). The system is composed of three proteins which mediate translocation of passenger antigens fused to the HlyA signal peptide directly to the extracellular medium.

So-called type III secretion systems (T3SS) are used by bacterial pathogens for the delivery of virulence factors across eukaryotic membranes (Hueck 1998). T3SS are very complex and cannot easily be transferred from one bacterial vector to another. However, naturally T3SS harboring vaccine strains can be efficiently subverted for the delivery of antigens directly into the cytosol of host cells (Russmann et al. 1998). This way, antigens can be targeted into MHC-I presentation pathway by extracellular or phagosome-restricted bacterial vectors (Russmann et al. 2003; Panthel et al. 2008). Nevertheless, the specificity of the T3SS for particular virulence factors renders these systems difficult for a general application of antigen secretion by gram-negative bacterial vaccine strains. In contrast, secretion systems from gram-positive bacteria are often less restricted to particular virulence factors and might allow the continuous secretion of antigens from the vaccine carrier (Buist et al. 2006).

\subsubsection{Delivery of Nucleic Acid Vaccines}

Already some time ago, the capability of bacteria to deliver nucleic acids into mammalian cells was discovered (Schaffner 1980). Meanwhile, bacteria-mediated transfer of plasmid DNA encoding vaccine antigens or therapeutic molecules was demonstrated in experimental animal models of infectious diseases, tumors, and gene deficiencies (Becker et al. 2008; Daudel et al. 2007; Loessner and Weiss 2004). Bacteria, competent to access the host cell cytoplasm, have been observed to display the highest transfer efficiency for nucleic acids (Courvalin et al. 1995; Dietrich et al. 1998; Sizemore et al. 1995). However, bacteria restricted to an intracellular vacuolar compartment such as Salmonella are also capable to mediate DNA transfer to a certain extent by an unknown mechanism (Darji et al. 1997). The use of an S. typhimurium strain lacking $\operatorname{ss} A B$, two essential genes for maintenance of phagosomal integrity during intracellular growth, improved the DNA delivery capacity of the vaccine strain (Bai et al. 2011). In addition, extracellular bacteria can mediate DNA delivery into mammalian cells by a conjugational apparatus (Kunik et al. 2001; Waters 2001). In comparison to other DNA delivery systems, bacterial vectors have a nearly unlimited capacity with regard to size. For instance, infectious virus could be reconstituted by the delivery of the complete genome of murine cytomegalovirus (MCMV) by a Salmonella vaccine strain into mammalian cells (Cicin-Sain et al. 2003). Specific silencing of mammalian genes was achieved with an engineered $E$. coli strain which could mediate the delivery of short hairpin RNA (shRNA) (Xiang et al. 2006). However, several bottlenecks have been identified which counteract the bacterial delivery of nucleic acids into mammalian cells. Cellular defense mechanisms such as autophagy (Ogawa et al. 2005), bacteria-induced cellular activation, or cell death (Fink and Cookson 2007) are factors that can restrict transfer efficiency. Nevertheless, bacteria-mediated gene transfer remains an attractive alternative for antigen delivery. Since the antigen is produced by the eukaryotic cells, obstacles like inefficient protein folding, posttranslational 
modification, or secretion can be circumvented. In addition, the bacteria represent a powerful adjuvant that helps to trigger efficacious immune responses.

\subsubsection{Delivery of Tumor Vaccines and Adjuvant Molecules}

The best examples for successful bacteria-mediated DNA vaccination are the experiments by the Reisfeld group using oral Salmonella vectors for delivery of anticancer vaccines (Reisfeld et al. 2004). Vaccine-mediated restriction of tumor angiogenesis was one approach of this work. As one of their targets, they used the vascular endothelial growth factor receptor (VEGFR2), also referred to as FLK-1. This molecule is not expressed by tumor cells but highly expressed on endothelial cells of growing tumor capillaries. When a eukaryotic FLK-1 expression plasmid was transferred orally by Salmonella to mice, animals were protected against subsequent challenge with different tumors, such as the MC38 colon carcinoma (Niethammer et al. 2002). Even 10 months after the vaccination, animals could resist such a challenge. Also, the use of so-called minigenes for expression of FLK-1 epitopes was successful to restrict tumor growth due to CD8 T-cell response (Luo et al. 2007). The advantage of such minimal coding sequences is that the probability of mutations is reduced and antigen delivery by bacteria is facilitated.

Another possible strategy is the use of a DNA vaccine for co-expression of cytokines or chemokines in conjunction with the antigen. IL-18 is a multifunctional cytokine and is able to improve tumor antigen presentation by DCs. Co-expression of the tumor antigen Fos-related antigen (Fra-1), which is overexpressed by many epithelial carcinomas, together with IL-18 mediated the reduction of metastases (Luo et al. 2005). In another approach, inhibition of angiogenesis was achieved by Salmonella-mediated oral delivery of the apoptosis protein survivin and the chemokine CCL21 in parallel, which attracts activated DCs and naïve T cells to the tumor site. Vaccination prevented pulmonary tumor growth and metastases and reduced the growth of already established tumors (Xiang et al. 2005). The expression of fibroblast activation protein (FAP) can be determined in approximately $90 \%$ of human epithelial tumors and is specific for stromal fibroblasts in solid tumors. The Salmonella-mediated delivery of a DNA vaccine against FAP enhanced the efficacy of doxorubicin chemotherapy and suppressed spontaneous metastases. In addition, this combination therapy inhibited tumor angiogenesis and reduced the expression of proliferative factors by the tumor microenvironment (Liao et al. 2009).

Attenuated strains of the gram-positive bacteria L. monocytogenes have also been studied in context of tumor vaccines. The bacteria are able to infect phagocytic and nonphagocytic cells and can spread in the body without being attacked by an antibody response. L. monocytogenes infection stimulates strong innate and adaptive immune response, rendering it an efficient vaccine vector candidate (Barbuddhe and Chakraborty 2008). In addition, the cytosolic intracellular residence of the bacteria favors a CD8 T-cell response that is necessary for the generation of antitumor immunity. To ensure bacterial secretion of the specific antigen, in most cases, the antigen is fused to a secretory bacterial protein such as LLO. One example of a $L$. monocytogenes tumor vaccine is a strain producing the 
human papillomavirus (HPV) antigen E7, which is associated with cervix and head and neck cancer (Gunn et al. 2001). In animals, this vaccine induces immune responses against E7 and causes regression of tumors which express the E7. In a phase I clinical trial, this vaccine was demonstrated to be safe in humans (Maciag et al. 2009). From 13 patients, five had progressed, seven had stable disease, and one qualified as a partial responder. Increased survival of patients was observed, from 180 to 347 days, and three patients were still alive 3 years after treatment. L. monocytogenes was also employed for the delivery of a prostate cancer vaccine. L. monocytogenes was engineered to deliver a LLO-PSA fusion protein. In a mouse model, it was demonstrated that this vaccine is immunogenic and causes regression of established PSA-expressing tumors (Shahabi et al. 2008).

\subsubsection{Tumor-Targeting Bacteria}

Apart from being powerful carriers for novel vaccination strategies, particular bacteria show also a potential to be used in cancer therapy. This is due to their ability to target and colonize tumors upon systemic administration (Leschner and Weiss 2010). Among the bacteria able to target tumors are anaerobics like Clostridia and Bifidobacteria as well as facultative anaerobics like Salmonella and $E$. coli. Interestingly, already in the nineteenth century, several physicians observed that cancer patients who caught an infection sometimes were cured from the tumor (Coley 1893). Even intentional infection of cancer patients mediated successful tumor cure in some cases; however, in most patients, the infection was fatal, and therefore, this approach was abandoned at that time. Today, with new options for attenuation and programming of bacteria, the development of cancer therapeutics based on living bacteria should become feasible.

Since most bacterial strains used for cancer therapy are pathogens, they first of all have to be attenuated. Some strains are under investigation that have been tested already as vaccine carriers like SL7207 ( $\triangle a r o A, ~ \triangle h i s G)$ (Leschner et al. 2009; Westphal et al. 2008; Yu et al. 2004), BRD509 ( $\triangle$ aroA, $\triangle$ aroD) (al-Ramadi et al. 2009; Yoon et al. 2007), and SL3261AT ( $\triangle$ aroA) (Avogadri et al. 2008; Yang et al. 2008). Such strains are deficient in synthesis of aromatic amino acids. Besides, there are also strains attenuated especially for the tumor-targeting purpose. One example is the Salmonella strain A1-R that was rendered auxotrophic for leucine and arginine and reisolated from tumors to enhance tumor specificity. It colonizes various human tumors and metastases in nude mice but is cleared rapidly from other organs (Hayashi et al. 2009a; Hayashi et al. 2009b; Kimura et al. 2010; Nagakura et al. 2009; Zhao et al. 2007, 2005, 2006). Another Salmonella strain considered to display an improved safety profile is VNP20009 ( $\triangle$ purI, $\Delta m s b B$ ). It produces a modified lipopolysaccharide and thus induces dramatically diminished levels of TNF- $\alpha$ in human peripheral leukocytes (Low et al. 1999). Unfortunately, VNP20009 did not readily colonize tumors of patients in phase I trials (Heimann and Rosenberg 2003; Toso et al. 2002). Possibly this strain is overattenuated since 
TNF- $\alpha$ was shown to play an important role in the invasion process of Salmonella into tumors (Leschner et al. 2009). Thus, presently, the major challenge in developing tumor-targeting bacteria is proper attenuation of the strain without restricting its capability to colonize the tumor tissue.

Apart from their inherent antitumor effect, some bacteria could be used as carriers to deliver therapeutic agents directly into the cancerous tissue. Different classes of molecules have been tested. One class represents immune modulatory molecules that should enhance the immune response toward the tumor or directly kill cancer cells. IL-2, IL-18, CCL21, LIGHT, and Fas ligand have been tested in this context (al-Ramadi et al. 2008, al-Ramadi et al. 2009; Loeffler et al. 2007, Loeffler et al. 2008a, b, 2009; Saltzman et al. 1996, 1997; Sorenson et al. 2008a, b). Toxic agents are another possibility to enhance anticancer effects of bacteria. For instance, the bacterial toxin cytolysin A resulted in strong reduction of tumor growth when expressed by tumor-colonizing S. typhimurium (Nguyen et al. 2010; Ryan et al. 2009). A third class of molecules are so-called prodrug-converting enzymes that convert nontoxic prodrugs into toxic substances. For example, thymidine kinase of the herpes simplex virus or E. coli cytosine deaminase has been used in this context (King et al. 2002; Nemunaitis et al. 2003; Pawelek et al. 1997; Royo et al. 2007). Tumor therapeutic bacteria mediating delivery of eukaryotic expression plasmids for therapeutic factors or interfering RNA species are also in development. In tumor therapeutic approaches, the use of proteins like thrombospondin-1, endostatin, Fms-like tyrosine kinase 3 (Flt3) ligand, but also the $E$. coli prodrug-converting enzyme purine nucleoside phosphorylase or apoptosisinducing proteins (TRAIL and Smac), led to efficient treatment of various tumors in mice (Fu et al. 2008a, b, c; Lee et al. 2004, 2005; Yoon et al. 2007). Similarly, siRNAs on eukaryotic plasmids targeting Stat-3 or the antiapoptotic protein bcl-2 showed their potential to be used in the treatment of tumors. Although promising, the mechanism leading to the effect is unclear. Salmonella are only rarely found inside of tumor cells or other host cells (Agorio et al. 2007; Loessner and Weiss 2007; Pawelek et al. 1997). Therefore, the question which cells can be the target for gene transfer still has to be answered. When constructing an efficacious anticancer bacterium, the regulation of therapeutic molecule expression is crucial. The use of particular promoters allows to predetermine the exact onset of therapeutic treatment as well as its termination, e.g., via the expression of suicide genes (Loessner et al. 2007). Therefore, inducible promoters like the $P_{B A D}$ promoter mentioned before enable to start the expression upon administration of the inducer substance at any desired time point (Loessner et al. 2007). Furthermore, tumor-specific promoters that exclusively drive protein expression inside of the neoplasia but not in any other tissue of the host are an important aspect to avoid side effects on healthy organs (Arrach et al. 2010; Leschner et al. 2011). Bacteria-mediated tumor therapy is often met with skepticisms despite the undisputed success in experimental and preclinical models. Although it will still require many iterative steps until it is converted into a general applicable therapeutic strategy, it undoubtedly has great potential. That certain tumors in human patients are colonized by bacteria demonstrates that future implementation of such a therapeutic option is realistic. 


\subsection{Live Attenuated Viral Vaccines and Viral Vaccine Vectors}

\subsubsection{Classical Viral Vaccines}

Almost all human and veterinary vaccines against viral diseases which are in use today are live attenuated or inactivated virus vaccines. Live virus vaccines are either derived from related low pathogenic viruses which enable cross-protection against the highly pathogenic virus strains (like the cowpox or vaccinia virus for vaccination against variola virus that causes smallpox) or derived by undirected attenuation of the viruses. Since they were all developed at a time when knowledge about the virus genomes and mechanisms of virulence were still lacking, mutagenesis of viruses was relatively random. In the past, attenuation of a virus was achieved by passaging in embryonated eggs or in animals of different vertebrate species followed by cell culture adaption. Later, with the establishment of standardized cell culture techniques, live virus vaccines were propagated in primary cells like chicken embryonic fibroblasts and human diploid cell lines (e.g., MRC-5) which have a definite life span. To facilitate the process of vaccine production, these cells are now successively being replaced by continuous cell lines (CCLs) due to improved characterization of these cells and widened analytical technologies able to determine their possible oncogenic potential. Thus far, only a small number of human vaccines are produced in CCLs (Gregersen et al. 2011). The African green monkey kidney cell line Vero is now the most widely accepted CCL by regulatory authorities and has been used for over 30 years for the production of polio and rabies virus vaccines (Barrett et al. 2009). Furthermore, vaccine manufacturers of seasonal and pandemic influenza vaccines are at various stages of developing cell-derived vaccines (Pandey et al. 2010). Vero cells or Madin-Darby canine kidney (MDCK) cells are often the CCLs of choice (Govorkova et al. 1996; Hu et al. 2011).

Current live viral vaccines are attenuated strains of poliovirus as well as measles, mumps, or rubella virus. In some countries, the latter are given as triple vaccine, called the MMR vaccine. These vaccines have been applied successfully and brought the world closer toward eradication of additional viral diseases, besides smallpox. Thus far, polio is eliminated from most parts of the world. Some European countries claim the eradication of measles virus. These achievements were possible because these viruses are restricted to the human host and do not persist in an animal reservoir. In addition, only one viral serotype (variola, mumps, measles, rubella) or very few serotypes (polio) exist. Thus, it is possible to induce protective antibody titers with a relatively simple vaccine composition. T-cell immunity is only known to play a role in the induction of protective immunity against measles virus (Griffin and Pan 2009), while the role of T cells for immunity against other viruses is still not clear.

Unfortunately, some countries still remain endemic for measles virus due to various factors, such as political problems, inappropriate health care systems, socioethical reasons, or inherent biological characteristics of the virus (Chumakov et al. 2007). However, also in some industrialized countries, compliance with routine 
vaccination of children has ceased to some extent. Hence, efforts of politics and health care professionals on the one hand and also the development of new vaccines are necessary in order to achieve the goal of global eradication of such viruses. For example, research on measles vaccines now includes also the development of DNA vaccines, subunit vaccines, and virus-vectored vaccines (Griffin and Pan 2009). Furthermore, the development of robust vaccines and simple application procedures is of great importance. In this regard, the development of thermostable vaccines or vaccines for needle-free application, e.g., aerosol administration, is in progress (Higginson et al. 2011). Moreover, the safety of measles vaccine in HIV-infected persons has to be improved (Strebel et al. 2003). Eradication of poliovirus was almost achieved using the trivalent polio vaccination. However, now, the monovalent oral polio vaccine (OPV) or inactivated polio vaccine (IPV) shall enable the complete eradication of polio (Ehrenfeld et al. 2009). Many live vaccines are in use for livestocks like bovine respiratory syncytial virus for cattle or calicivirus in cats. Thus far, the most successful live viral vaccine is the "Rinderpest" vaccine. It has succeeded to completely eradicate the disease in 2011.

The use of an inactivated virus as vaccine is an alternative to the application of viral LAV. One advantage is that pathogenic viral isolates can be used. Today, inactivated vaccines are produced against tick-borne encephalitis virus, hepatitis A virus, seasonal influenza, Japanese encephalitis virus, rabies and yellow fever, and a spectrum of veterinary viral diseases. Inactivated vaccines have the advantage of increased safety since they are not able to replicate in cells of the vaccinated host and therefore do not spread to contacts. However, due to their replication deficiency, such vaccines stimulate mainly antibody responses. Moreover, during the inactivation process, e.g., the action of formaldehyde, the antigenicity of the vaccine might be reduced due to the destruction of protective epitopes (FraenkelConrat and Mecham 1949; Metz et al. 2003). Thus, inactivated viruses often do not reach the same efficacy as live attenuated virus, and a protective immune response is not always elicited (Fig. 5.3).

The efficacy obtained with live virus vaccines in some cases prevented further development of inactivated vaccines. However, the use of adjuvants, alternative inactivation procedures, or vaccine compositions may allow the generation of new inactivated vaccines with increased efficacy, able to induce antibody as well as T-cell-mediated immune responses (Amanna and Slifka 2009). Nevertheless, despite improved safety requirements, research on live attenuated viruses is also maintained. For instance, a cold-adapted seasonal influenza vaccine has recently been approved in the USA (Kreijtz et al. 2009).

\subsubsection{Recombinant Antiviral Subunit Vaccines}

Recombinant biotechnology allowed the development of two successful viral subunit vaccines for humans, against the hepatitis B virus (HBV) and the human papillomavirus (HPV). The HBV vaccine was registered in 1984. It is highly 


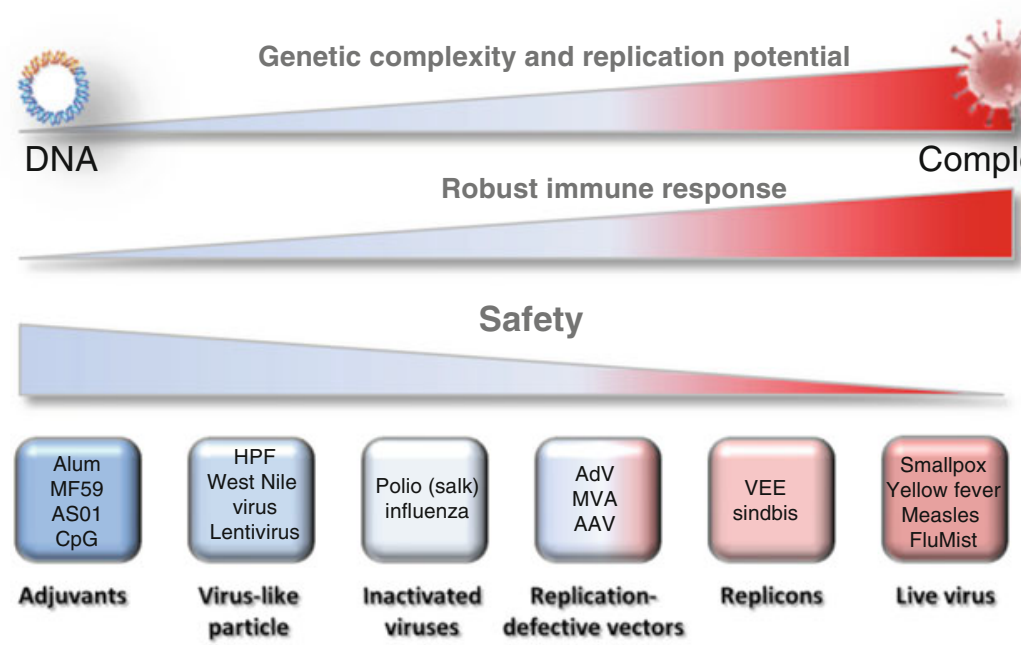

Fig. 5.3 From naked adjuvanted vaccines to live viruses - the balance between genetic complexity, strong immune response, and safety. There is an intrinsic mismatch between safety on the one side and potent immune induction translating into protection on the other side. Highly attenuated replication-defective viral vectors have been developed as a system balancing the benefit of maximized immunogenicity and strongest safety. ASO1 adjuvant system 01, MF59 oil-in-water emulsion adjuvant, $V L P$ virus-like particle, $A d V$ adenovirus, $M V A$ modified vaccinia virus Ankara, $A A V$ adeno-associated virus, $V E E$ Venezuelan equine encephalitis virus

protective and reduced in endemic areas dramatically hepatocellular carcinoma that is a sequel of chronic HBV infection. The HBV vaccine is produced in yeast or mammalian $\mathrm{CHO}$ cells and consists of a recombinant surface protein of the virus, the HBsAg (McAleer et al. 1984; WHO 2009). The two major yeast-derived hepatitis $\mathrm{B}$ vaccines that are licensed in most countries are given as a monovalent vaccine; however, formulations with a hepatitis A vaccine are also available (Previsani and Lavanchy 2002). The HPV vaccine is directed against virus-induced cervical cancer, some vulvar and vaginal cancers and some genital warts in young women and men. Two prophylactic HPV vaccines were approved in Europe and the USA in 2007. They both target the HPV serotypes 16 and 18 or additionally 6 and 11 and consist of the yeast or insect cell-produced shell L1 protein that selfassembles into virus-like particles (GlaxoSmithKline 2011; Merck\&CO 2011; WHO publication 2008).

\subsubsection{Recombinant Viral Vectors for Novel Vaccine Developments}

Vaccines against a range of viral diseases are not yet available. This does not only concern new emerging viruses like West Nile virus or newly arising pandemic influenza viruses, e.g., H5N1 or H1N1, but also HIV and zoonotic viruses. Such viruses often establish quickly a quasi-species in the host with a variant serology as 
an immune escape mechanism against host immune surveillance. This unfortunately includes vaccine-induced immunity, making conventional vaccine development extremely difficult. Thus, novel vaccines based on recombinant microbes define nowadays future developments to conquer such diseases. Different viruses are now exploited for the development of recombinant vaccines that include members of the family of poxvirus, adenovirus, lentivirus, retrovirus, alphavirus, rhabdovirus, as well as vesicular stomatitis virus (Fig. 5.4). Here, the virus builds the backbone of a prophylactic or therapeutic vaccine for the delivery of heterologous antigens. The large panel of different viruses exhibiting different features

\section{Human}

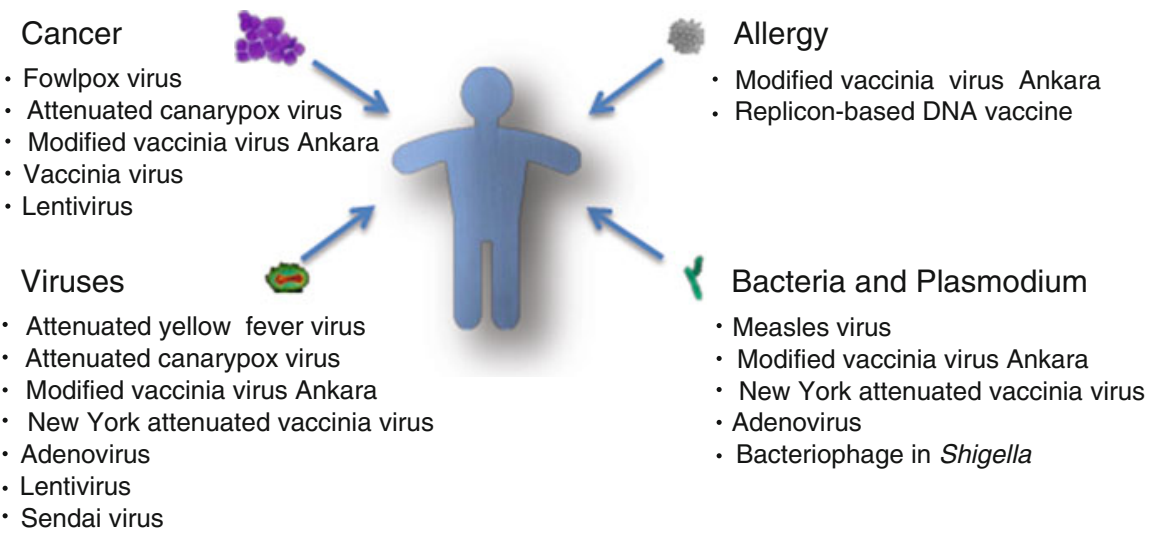

\section{Veterinary}

\section{Viruses}

- Adenovirus

- Attenuated canarypox virus

- Fowlpox virus

- Newcastle disease virus

- Turkey herpesvirus

- Attenuated yellow fever virus

- Vaccinia virus
Bacteria and Plasmodium

- Adenovirus

- Modified vaccinia virus Ankara

Fig. 5.4 Human and veterinary viral vaccine vectors. Different viruses are developed as viral vector vaccines. Some are investigated in clinical trials directed against either pathogens such as viruses, bacteria, and parasites or other diseases (e.g., cancer, allergy) 
provides the possibility to exploit diverse immune-stimulating capacities as well as the potential to deliver antigens to different immune inductive sites. Together with prime-boost applications as well as adjuvant delivery, a wide range of possibilities are provided to suffice requirements to fight many particular diseases.

Several recombinant vaccines have been successfully introduced into the veterinary practice. Canarypox and fowlpox vector vaccines, baculovirus-expressed viral antigens, and even DNA vaccines build the second generation of licensed veterinary vaccines (Meeusen et al. 2007). Vector vaccines for humans are not yet approved, but promising preclinical and clinical data have been obtained and will be discussed below.

\subsubsection{Attenuated Vaccinia Viruses}

During the vaccination campaign against smallpox, severe side effects were tolerated. Such side effects included generalized vaccinia, unwanted spreading to unprotected contact persons, or even life-threatening reactions like eczema vaccinatum, vaccinia necrosum, and postvaccinal encephalitis. However, despite sporadic occurrence of zoonotic poxvirus infections and the threat of bioterrorism today, such side effects are nowadays intolerable. Therefore, besides the continuous use of the vaccinia virus (VACV) vaccine Dryvax for certain person groups in the USA, attenuated strains have been developed. These are the modified vaccinia virus Ankara (MVA) derived from the chorioallantois virus strain Ankara (Mayr et al. 1975), the New York VACV (NYVAC) based on the Copenhagen strain of VACV (Tartaglia et al. 1992), and LC16m8 derived from the VACV Lister strain (Kenner et al. 2006).

Like conventional VACV, MVA and NYVAC potently induce humoral and cellular immune responses. However, these vaccines considerably differ in their immune-stimulating capacity. MVA was generated by passaging the virus more than 500 times in chicken embryonic fibroblasts, whereby it gained many deletions and point mutations resulting in the loss of about $15 \mathrm{~kb}$ of DNA in comparison to its parental strain. In contrast, NYVAC received deletions of 18 particular genes. In both viruses, the function of several immune suppressive genes was lost. As a result of their genetic diversity, MVA and NYVAC differentially stimulate the immune response of the host. For example, distinct gene expression profiles were induced upon infection of human monocyte-derived dendritic cells (Guerra et al. 2007; Najera et al. 2006). Moreover, a parallel comparison of both vectors to determine vaccine efficacy in a macaque HIV model showed a more CD4+ T-cell-driven immune response for NYVAC, whereas MVA induced CD8+ as well as CD4+ Tcell responses to the heterologous vaccine antigens (Mooij et al. 2008). The molecular and immunological basis of innate and adaptive immune stimulation of these viruses is now under intense investigation. Interestingly, MVA has a unique ability to induce type I interferons and a spectrum of chemokines and cytokines in contrast to VACV (Guerra et al. 2007; Lehmann et al. 2009; Waibler et al. 2007).

Due to their genomic deletions, MVA and NYVAC have lost the capacity to replicate in most mammalian cells and consequently cannot spread in vivo (Drexler et al. 1998; Gomez et al. 2007; Meyer et al. 1991; Tartaglia et al. 1992). Both 
viruses were tested in several animal models and found to be highly attenuated in comparison to VACV. Moreover, MVA has already been used in humans. It was proven to exhibit an excellent safety profile when applied to 120,000 humans including high-risk patients still during the poxvirus eradication program (Mayr et al. 1978). Later, several phase I clinical trials with different MVA vector vaccines administered at high doses confirmed this safety profile of MVA (Goepfert et al. 2011; von Krempelhuber et al. 2010; Wilck et al. 2010). In comparison with other viral vectors, it is of note that MVA and NYVAC like other poxviruses replicate exclusively in the cytoplasm of infected cells making a gene transfer event into the host cell genome unlikely.

Despite the lack of productive infection, MVA and NYVAC exert a full gene expression profile and are suitable to mediate high-level production of recombinant antigens (Sutter and Moss 1992; Tartaglia et al. 1992). Well-defined protocols for generation of recombinant viruses are established using homologous recombination technology and plaque selection with the help of different marker genes (Carroll and Moss 1995; Staib et al. 2000). More recently, recombinant VACV and MVA vaccines have been generated by the use of bacterial artificial chromosomes which further simplifies the construction of vector vaccines (Cottingham et al. 2008; Domi and Moss 2002). The viruses tolerate large inserts of foreign sequences into their double-stranded DNA genomes and are normally very stable. MVA can be produced in large amounts and can even be used as dried vaccine. Thus, it will be suitable also for the application in areas where the cooling chain cannot be guaranteed. In addition, mucosal needle-free application of freeze-dried MVA into mice clearly demonstrated the potency of this formulation to induce immune responses comparable to parenteral application. Protection against lethal bacterial and viral challenges was generated this way (Kastenmuller et al. 2009). These features proof recombinant MVA or VACV to be simple and safe vaccine platforms for general application. Both MVA and NYVAC were developed as vector vaccines against a diverse set of infections, cancer, and allergic diseases. Besides the use of MVA directly as poxvirus vaccine, MVA-based vector vaccines against HIV, malaria, and different cancers and allergies are investigated preclinically and also in clinical phase I and/or II trials (Albrecht et al. 2008; Gomez et al. 2011).

\subsubsection{Avipoxviruses}

Canarypox and fowlpox are avipoxviruses which have been used since some time as vector vaccines. Both avipoxviruses have a strict host tropism to birds but contain the ability to infect mammalian cells and strongly express heterologous antigens without completion of the virus life cycle. This constitutes an important safety feature for these live attenuated virus vectors. Canarypox was shown to elicit humoral and cellular immune responses in vaccinated subjects (Zanotto et al. 2010). Interestingly, recombinant canarypox was found being able to induce a 100-fold stronger protective immune response compared to a similar fowlpox vaccine (Taylor et al. 1991). Today, several canarypox-based veterinary vaccines are in routine use (Poulet et al. 2007), of which most are based on the ALVAC strain, a plaque isolate of the canary vaccine Kanapox. For humans, an ALVAC- 
based HIV vaccine (ALVAC-HIV, vCP1521) expressing the glycoprotein gp120 of clade $\mathrm{B} / \mathrm{E}$ is currently tested in a phase III clinical trial (Rerks-Ngarm et al. 2006). In contrast to a trial where the recombinant vaccine was given alone, a prime-boost regimen together with a recombinant HIV glycoprotein subunit vaccine (AIDSVAX) gave encouraging results. In this efficacy trial performed in Thailand, HIV acquisition was significantly reduced in the vaccine group (Vaccari et al. 2010).

\subsubsection{Measles Viruses}

Measles virus, also known as rubeola or morbilli, is an enveloped, single-stranded, negative-sense RNA virus which infects the respiratory system. It belongs to the family Paramyxoviridae of the genus Morbillivirus. In developed countries, most children are immunized against measles. However, worldwide, approximately 200,000 children die of measles each year. Immune responses induced by routine vaccination represent a problem for the use of recombinant measles vector vaccines. On the other hand, the extensive clinical experience with the adapted measles vaccines, their rare side effects, and their capacity to induce a strong often lifelong immunity renders measles virus highly suitable as a vaccine vector. To use a nonsegmented negative-strand RNA virus (Mononegavirales) as vector is possible nowadays by state-of-the-art molecular methods to produce cDNA clones. These technologies allow site-directed mutagenesis to study gene functions as well as to insert foreign coding sequences to develop multivalent vaccines against measles and other pathogens. The use of measles virus as vector was experimentally promoted by its high genetic stability, which is unexpected for RNA viruses, and by its acceptance of foreign sequences. For quite a while, it was not possible to convert measles virus into a vaccine vector, but in the meantime, appropriate replicons, helper cells, and helper viruses were constructed (Collins et al. 1993, 1991; Conzelmann and Schnell 1994; Martin et al. 2006; Schneider et al. 1997; Sidhu et al. 1995; Takeda et al. 2005). The newly developed systems allow the insertion of additional transcription units for heterologous antigens. The maximal insertion capacity tolerated by the virus is $6 \mathrm{~kb}$, and expression level of the inserted gene depends on the position within the viral genome (Billeter et al. 2009; Hangartner 1997; Singh et al. 1999; Wang et al. 2001; Zuniga et al. 2007). Measles-based vector vaccines are considered as candidates for multivalent vector vaccines expressing antigens of hepatitis B (del Valle et al. 2007; Singh et al. 1999), SIV/HIV (Brandler and Tangy 2008; Lorin et al. 2004; Tangy and Naim 2005; Wang et al. 2001; Zuniga et al. 2007), West Nile, Dengue virus (Brandler and Tangy 2008; Despres et al. 2005), and SARS coronavirus (Liniger et al. 2008). Several studies in mouse models have shown that recombinant measles vaccines are capable of inducing humoral immunity against both measles and heterologous antigens (de Vries et al. 2008). The first candidate vaccine "HIV-measles," which was developed in the last few years by the Tangy group at the Pasteur Institute, should enter soon into the clinical testing phase. 


\subsubsection{Yellow Fever Virus}

Yellow fever is an acute viral hemorrhagic disease caused by an enveloped, singlestranded, positive-sense RNA virus of the Flaviviridae family. Surviving an infection by yellow fever virus results in lifelong immunity, and normally no permanent organ damage is encountered in such individuals (Schmaljohn and McClain 2011). The original yellow fever vaccine is a live attenuated virus based on the 17D yellow fever virus strain (YFV-17D). It was developed almost 70 years ago by empirical methods and is still considered to be one of the safest and most effective virus vaccines. Starting from this vaccine, live attenuated chimeric viruses were constructed by replacing the genes coding for premembrane (prM) and envelope (E) proteins of the YFV-17D vaccine strain with such of heterologous flaviviruses (ChimeriVax technology) or the gene Japanese encephalitis virus (JE) encoding the JE preM-Env protein (Draper and Heeney 2010). The latter chimera has completed phase III trials and is currently in preregistration. The JE vaccine, previously known as ChimeriVax-JETM, is supposed to become the first approved human viral vector vaccine (Appaiahgari and Vrati 2010).

\subsubsection{Adenoviruses}

Human adenoviruses belong to the family Adenoviridae. Viruses of this family infect both humans and animals. Adenoviruses are nonenveloped icosahedral viruses assembled from a nucleocapsid that harbors the double-stranded linear DNA genome. There are 53 serotypes of adenoviruses in humans with variable morphology (Kaufman 2011). The virus is responsible for 5-10\% of ocular, respiratory, or gastrointestinal epithelium infections in children and also adults. Already in 1977, a cell line was established that enabled the production of recombinant adenoviruses in a helper-free environment. Since this landmark, adenoviral vectors have received attention as gene transfer agents for gene therapy and for vector-based vaccinations (Randrianarison-Jewtoukoff and Perricaudet 1995). Attenuation is usually achieved by deleting the E1A gene that is known to be essential for adenoviral replication (Carlock and Jones 1981; Gaynor and Berk $1983)$. The $\Delta \mathrm{E} 1 \mathrm{~A}$ vectors are able to infect cells without causing any cellular damage. In the first vector generation, $\mathrm{E} 1$ and $\mathrm{E} 3$ were deleted $(\Delta \mathrm{E} 1 / \mathrm{E} 3)$ because the $\mathrm{E} 3$ region is not essential for in vitro vector production. The adenovirus vector is able to deliver genes with nearly $100 \%$ efficiency to a wide range of cell types including dividing or nondividing cells as well as primary cells, and it is possible to produce extremely high viral titers. Adenoviral vectors provide a capacity of up to $8 \mathrm{~kb}$ of foreign recombinant genes. In the classical adenovirus vector generation, the recombinant genes are inserted into the deleted E1A region of a viral cDNA by in vitro ligation and homologous recombination protocols (Wolff and Lederberg 1994). A new approach allows the generation of recombinant adenoviruses by Tn7mediated transposition in E. coli (Richards et al. 2000). For the viral production, normally modified 293 cells are utilized. These cells are stably transfected with the E1A region of the adenoviral genome and allow the vector to replicate and mature. The resulting vector particle prepared from this cell line will lack the E1A region and remain replication deficient. As with any viral vector system, it has to be 
ensured that the produced vector is not contaminated with the wild-type virus. In the adenoviral system, two homologous recombination events must occur to restore wild-type virus rendering this event highly unlikely.

Adenovirus vectors strongly induce the innate arm of the immune system that results in inflammation of infected tissues and efficient clearance of administered vectors (Muruve 2004). Adenovirus vector vaccines are developed against a variety of different infectious diseases and have entered clinical trials for malaria (phase I), HIV-1 (Fitzgerald et al. 2011), different cancers, and others malignancies (CR Health Net 2011).

\subsubsection{Virus-Like Particles and Other Viral Vector Systems}

Virus-like particles (VLPs) are also considered as vector vaccines despite they are nonliving empty viral particles. These so-called pseudoviruses are noninfectious because they lack any viral genetic information which is normally packaged into such particles. For this technique, the capacity of viral structural proteins such as envelope or capsid to self-assemble into VLPs was exploited (Kirnbauer et al. 1992; Kost and Condreay 1999; Valenzuela et al. 1982). VLPs of HBsAg derived from HBV were already described over 40 years ago from infected patient sera (Bayer et al. 1968). Nowadays, VLPs are produced for the licensed HPV vaccine and additionally from a whole variety of other virus families including Parvoviridae (e.g., adeno-associated virus), Retroviridae (e.g., HIV), Polyomaviridae (e.g., JC virus) (Chang et al. 2011), Paramyxoviridae (e.g., Nipah virus) (Walpita et al. 2011), and Flaviviridae (e.g., hepatitis C virus). Despite their limited immune stimulatory capacity, VLPs are attractive vaccine candidates due to their higher safety level compared to LAV (Fig. 5.3). VLPs can be produced in different cell culture systems including mammalian and rodent cell lines, insect cell lines, yeast, and also plant cells (Santi et al. 2006). For VLP vaccines, the foreign antigen is normally fused to the viral envelope protein or to a membrane domain, guiding and anchoring the antigen to the surface of the viral particle. The VLP presents the antigen to the immune system in its natural length and native structure. The particulate nature of the vaccine promotes immune recognition of the heterologous antigen (Bach et al. 2009; Hunter et al. 2011; Li et al. 2004; Nikles et al. 2005; Walpita et al. 2011). Until today, there are different antigens tested for their capacity to induce a protective immunity or to break immunological tolerance. Thus far, no VLP-based vector vaccine has entered clinical testing phase.

A new vaccine approach against HIV was developed in the macaque AIDS model using pathogenic SIVmac239 as disease-inducing agent. For vaccination, rhesus cytomegalovirus (RhCMV), a replication competent and persistent but normally harmless virus, was equipped with a set of SIV antigens. This vaccine was shown to completely control SIV infection and spreading in some of the infected animals which was normally not achieved with the more common prime-boost strategies with highly immune activating but replication incompetent viral vectors. The continuous antigen delivery by the RhCMV/SIV vaccine in combination with the ability to stimulate an effector memory $\mathrm{T}$-cell response was 
suggested as reason for this vaccination success (Hansen et al. 2011). Such vector systems might provide a new way for the development of effective HIV vaccines.

\subsubsection{Oncolytic Viruses}

In the last century, clinical observations reported that cancer regression coincided with virus infections. However, tumor regression was mostly transient and incomplete (Kelly and Russell 2007; Sinkovics and Horvath 1993). At that time, there was no knowledge on virus infections, immune responses, and the correlate to tumor regression, and therefore, the use of oncolytic viruses today demands the investigation of those parameters. Reovirus, vaccinia, measles, adeno, herpes, vesicular stomatitis virus, as well as Newcastle disease virus, are the viruses mainly considered for therapies of cancer by oncolysis. The first approved oncolytic virus H101 has been approved in 2005 in China but not in Europe or the USA (Kirn 2006). It is a $\triangle \mathrm{E} 1 \mathrm{~B}$ adenovirus variant. For the improvement of safety, i.e., the tumor-specific infection and replication as well as efficacy, i.e., destruction of the tumor and eventually also metastases, it is essential to understand viral tropism and host restriction in addition to the influence of the molecular phenotype of the tumor. Techniques to specifically modify viruses for a rational design and the development of safe and efficient oncolytic viruses are already available. For instance, retargeting through modification of viral envelope proteins or their substitutions as well as activation or restriction of viral replications through specific viral gene deletions are necessary to generate safe and tumor-specific viruses. In addition, arming and shielding oncolytic viruses will improve oncolytic efficacy. Arming refers to equipping the virus with genes encoding prodrug-converting enzymes or immune stimulatory proteins to enhance antitumor activity. Shielding can be done chemically or biologically by using different viral serotypes to prevent neutralization by preexisting virus-specific antibodies (Cattaneo et al. 2008).

Recent reports indicate synergistic effects between direct viral oncolysis and activation of specific antitumor immune responses. This suggests the inclusion of immunotherapeutic approaches into viral antitumor therapy (Boisgerault et al. 2010). Among various immunomodulatory proteins that have been proposed, the most successfully employed immune-stimulating factor in advanced oncolytic viruses is the granulocyte-macrophage colony-stimulating factor (GMCSF). A second molecule is interferon- $\beta$, although recombinant viruses harboring the corresponding gene have not entered clinical trials yet (Melcher et al. 2011). Besides, proteases, glycosidases, and strategies that target angiogenesis are also tested with respect to their antitumor activity (Boisgerault et al. 2010).

\subsection{Animal Models}

To study the safety and efficacy of a new vaccine candidate, preclinical evaluation in animals precedes in most cases testing in humans. Various mouse models are often used to establish first proof of concept for a new vaccine in vivo with regard to 
Table.5.2 Overview of the features of viral vectors

\begin{tabular}{|c|c|c|c|c|c|}
\hline & $\begin{array}{l}\text { Human adenovirus } \\
\text { (HAdV) }\end{array}$ & $\begin{array}{l}\text { Modified } \\
\text { vaccinia virus }\end{array}$ & Measles virus & Yellow fever & $\begin{array}{l}\text { Canarypox } \\
\text { virus }\end{array}$ \\
\hline Family & Adenoviridae & Poxviridae & Paramyxoviridae & Flaviviridae & Poxviridae \\
\hline Genus & Mastadenovirus & Orthopoxvirus & Morbillivirus & Flavivirus & Avipoxvirus \\
\hline Species & Six species $(\mathrm{A}-\mathrm{F})$ & Vaccinia virus & Paramyxoviruses & $\begin{array}{l}\text { Natural forms: } \\
\text { urban yellow fever, } \\
\text { sylvatic yellow fever } \\
\text { For vaccines used: } \\
\text { 17D yellow fever } \\
\text { virus strain }\end{array}$ & $\begin{array}{l}\text { Fowlpox } \\
\text { virus }\end{array}$ \\
\hline Serotypes & 53 Serotypes & & & & \\
\hline Genome & $\begin{array}{l}34-43 \mathrm{~kb} \text { double- } \\
\text { stranded DNA }\end{array}$ & $\begin{array}{l}178 \mathrm{~kb} \\
\text { double- } \\
\text { stranded DNA }\end{array}$ & $\begin{array}{l}\text { Single-stranded, } \\
\text { negative-sense } \\
\text { RNA }\end{array}$ & $\begin{array}{l}\text { Single-stranded, } \\
\text { positive-sense RNA }\end{array}$ & $\begin{array}{l}\text { Double- } \\
\text { stranded } \\
\text { DNA }\end{array}$ \\
\hline $\begin{array}{l}\text { Cellular } \\
\text { receptors }\end{array}$ & $\begin{array}{l}\text { Coxsackie adenovirus } \\
\text { receptor, heparin- } \\
\text { sensitive receptor, } \\
\text { CD46, CD80, and CD86 }\end{array}$ & Unknown & $\begin{array}{l}\text { SLAM and } \\
\text { CD } 46\end{array}$ & $\begin{array}{l}\text { In discussion: } \\
\text { Glycosaminoglycans }\end{array}$ & \\
\hline $\begin{array}{l}\text { Insert } \\
\text { capacity }\end{array}$ & $\sim 7.5 \mathrm{~kb}$ & $25 \mathrm{~kb}$ & $6 \mathrm{~kb}$ & & \\
\hline
\end{tabular}

its safety and efficacy. Since pathogen-host interaction differs between mouse and human, careful selection of the pathogen for challenge experiments and the appropriate mouse strain (or an alternative animal model) is necessary in order to obtain relevant data.

For example, in the case of efficacy testing of poxvirus vaccines, the most common challenge model uses the lab-adapted VACV strain Western Reserve in mice. Even though special safety equipment is demanded for work with ectromelia virus, however, as the natural mouse pathogen causing mousepox, this virus resembles much more the course of disease progression of a variola virus in humans than the Western Reserve strain. To define the best route of challenge, virus administration is also important. Besides footpad inoculation, intranasal infection appears to mimic a more natural route of poxvirus infection. Thus, this virusanimal model represents an optimal small animal model to study MVA and orthopoxvirus immunogenicity and vaccine success (Paran et al. 2009; Paran and Sutter 2009). Other viruses, e.g., HIV, measles virus, and Ebola virus, cannot infect or replicate in mice due to strict host specificity. For such viruses, other target animals such as monkeys are needed. In the case of HIV, infection of macaques with the simian immunodeficiency virus (SIV) is still an important animal model for the understanding of HIV pathogenesis and the development of novel HIV vaccines. A natural SIV variant defective in the Nef gene function was found to induce protective immunity against an SIV challenge and thus can provide a valid tool to study the immune parameters that confer protection against the challenge virus (Daniel et al. 1992). However, due to ethical concerns and high costs, low numbers of animals can be used in experimental settings. An alternative attempt is made to develop new mouse strains transgenic for human components. For example, a mouse transgenic for the human SLAM receptor enabled measles virus infection 
and replication in otherwise resistant mice (Ohno et al. 2007). Additionally, immunogenic parameters that would also be representative for humans cannot always be found in animal models. Therefore, so-called humanized mice are developed which lack parts of their own immune system and thus can be reconstituted with human hematopoietic stem cells from which functional human immune cells can develop (Legrand et al. 2009). Similarly, humanized mice have been successfully tested in infection experiments using $S$. typhi, a bacterial pathogen that is exclusively restricted to humans (Song et al. 2010). Although the procedure to humanize mice is experimentally still very challenging, it is reasonable to expect that this system will be more and more introduced into testing of vaccines and therapeutics for intended human use.

\subsection{Conclusion and Outlook}

The use of LAV has made an indispensable contribution in the fight against infectious diseases. While initially undirected mutagenesis or extended passaging was employed to render the vaccine safe, today, modern molecular genetics allows the rational design of live microbes as a more efficient and safer vaccine or as vector systems for the delivery of heterologous prophylactic and therapeutic macromolecules. A number of bacterial, viral, and in some cases eukaryotic vector systems are considered as prospective carriers for protein, nucleic acid, or polysaccharide cargos. In addition to vaccination, live vectors offer new routes for the treatment of various disorders, such as cancer, gene deficiencies, allergies, or autoimmune diseases. However, the introduction of a new generation of recombinant live vector systems into medical practice is a long endeavor. In order to meet all requirements for approval, the safe, efficacious, and controlled use of such systems has to be carefully demonstrated in preclinics and the clinics. In addition, risks associated with genetically modified LAV, which might be released into the environment, have to be comprehensively assessed. The recent introduction of several recombinant bacterial and viral LAV into practice is a valuable proof of concept and will help to pave the roads for the development of such vaccines in the future.

\section{References}

Agorio C, Schreiber F, Sheppard M, Mastroeni P, Fernandez M, Martinez MA, Chabalgoity JA (2007) Live attenuated Salmonella as a vector for oral cytokine gene therapy in melanoma. J Gene Med 9:416-423

Albrecht M, Suezer Y, Staib C, Sutter G, Vieths S, Reese G (2008) Vaccination with a modified vaccinia virus ankara-based vaccine protects mice from allergic sensitization. J Gene Med 10:1324-1333

al-Ramadi BK, Fernandez-Cabezudo MJ, El-Hasasna H, Al-Salam S, Attoub S, Xu D, Chouaib S (2008) Attenuated bacteria as effectors in cancer immunotherapy. Ann N Y Acad Sci $1138: 351-357$ 
al-Ramadi BK, Fernandez-Cabezudo MJ, El-Hasasna H, Al-Salam S, Bashir G, Chouaib S (2009) Potent anti-tumor activity of systemically-administered IL2-expressing Salmonella correlates with decreased angiogenesis and enhanced tumor apoptosis. Clin Immunol 130:89-97

Amanna IJ, Slifka MK (2009) Wanted, dead or alive: new viral vaccines. Antiviral Res 84:119-130

Appaiahgari MB, Vrati S (2010) IMOJEV ${ }^{\circledR}$ : a Yellow fever virus-based novel Japanese encephalitis vaccine. Expert Rev Vaccines 9:1371-1384

Arrach N, Cheng P, Zhao M, Santiviago CA, Hoffman RM, McClelland M (2010) High-throughput screening for salmonella avirulent mutants that retain targeting of solid tumors. Cancer Res 70:2165-2170

Avogadri F, Mittal D, Saccheri F, Sarrafiore M, Ciocca M, Larghi P, Orecchia R, Rescigno M (2008) Intra-tumoral Salmonella typhimurium induces a systemic anti-tumor immune response that is directed by low-dose radiation to treat distal disease. Eur J Immunol 38:1937-1947

Bach P, Tschape JA, Kopietz F, Braun G, Baade JK, Wiederhold KH, Staufenbiel M, Prinz M, Deller T, Kalinke U, Buchholz CJ, Muller UC (2009) Vaccination with Abeta-displaying viruslike particles reduces soluble and insoluble cerebral Abeta and lowers plaque burden in APP transgenic mice. J Immunol 182:7613-7624

Bai Y, Gong H, Li H, Vu GP, Lu S, Liu F (2011) Oral delivery of RNase P ribozymes by Salmonella inhibits viral infection in mice. Proc Natl Acad Sci USA 108:3222-3227

Barbuddhe S, Chakraborty T (2008) Biotechnological applications of Listeria's sophisticated infection strategies. Microb Biotechnol 1:361-372

Barrett PN, Mundt W, Kistner O, Howard MK (2009) Vero cell platform in vaccine production: moving towards cell culture-based viral vaccines. Expert Rev Vaccines 8:607-618

Barrow PA (2007) Salmonella infections: immune and non-immune protection with vaccines. Avian Pathol 36:1-13

Bayer ME, Blumberg BS, Werner B (1968) Particles associated with Australia antigen in the sera of patients with leukaemia, Down's Syndrome and hepatitis. Nature 218:1057-1059

Becker PD, Noerder M, Guzman CA (2008) Genetic immunization: bacteria as DNA vaccine delivery vehicles. Hum Vaccin 4:189-202

Bernhardt TG, Roof WD, Young R (2000) Genetic evidence that the bacteriophage phi X174 lysis protein inhibits cell wall synthesis. Proc Natl Acad Sci USA 97:4297-4302

Billeter MA, Naim HY, Udem SA (2009) Reverse genetics of measles virus and resulting multivalent recombinant vaccines: applications of recombinant measles viruses. Curr Top Microbiol Immunol 329:129-162

Boisgerault N, Tangy F, Gregoire M (2010) New perspectives in cancer virotherapy: bringing the immune system into play. Immunotherapy 2:185-199

Bowe F, O'Gaora P, Maskell D, Cafferkey M, Dougan G (1989) Virulence, persistence, and immunogenicity of Yersinia enterocolitica O:8 aroA mutants. Infect Immun 57:3234-3236

Brandler S, Tangy F (2008) Recombinant vector derived from live attenuated measles virus: potential for flavivirus vaccines. Comp Immunol Microbiol Infect Dis 31:271-291

Brown A, Hormaeche CE, de Demarco H, Winther M, Dougan G, Maskell DJ, Stocker BA (1987) An attenuated aroA Salmonella typhimurium vaccine elicits humoral and cellular immunity to cloned beta-galactosidase in mice. J Infect Dis 155:86-92

Buddle BM, Wedlock DN, Denis M (2006) Progress in the development of tuberculosis vaccines for cattle and wildlife. Vet Microbiol 112:191-200

Buist G, Ridder AN, Kok J, Kuipers OP (2006) Different subcellular locations of secretome components of Gram-positive bacteria. Microbiology 152:2867-2874

Bumann D (2001) Regulated antigen expression in live recombinant Salmonella enterica serovar Typhimurium strongly affects colonization capabilities and specific CD4(+)-T-cell responses. Infect Immun 69:7493-7500

Calmette A, Guerin C, Boquet A, Negre L (1927) Prophylactic vaccination against tuberculosis using "BCG". Masson, Paris 
Carlock LR, Jones NC (1981) Transformation-defective mutant of adenovirus type 5 containing a single altered E1a mRNA species. J Virol 40:657-664

Carroll MW, Moss B (1995) E. coli beta-glucuronidase (GUS) as a marker for recombinant vaccinia viruses. Biotechniques 19:352-354

Cattaneo R, Miest T, Shashkova EV, Barry MA (2008) Reprogrammed viruses as cancer therapeutics: targeted, armed and shielded. Nat Rev Microbiol 6:529-540

Chang CF, Wang M, Ou WC, Chen PL, Shen CH, Lin PY, Fang CY, Chang D (2011) Human JC virus-like particles as a gene delivery vector. Expert Opin Biol Ther 11:1169-1175

Chatfield SN, Charles IG, Makoff AJ, Oxer MD, Dougan G, Pickard D, Slater D, Fairweather NF (1992a) Use of the nirB promoter to direct the stable expression of heterologous antigens in Salmonella oral vaccine strains: development of a single-dose oral tetanus vaccine. Biotechnology (NY) 10:888-892

Chatfield SN, Fairweather N, Charles I, Pickard D, Levine M, Hone D, Posada M, Strugnell RA, Dougan G (1992b) Construction of a genetically defined Salmonella typhi Ty2 aroA, aroC mutant for the engineering of a candidate oral typhoid-tetanus vaccine. Vaccine 10:53-60

Cheminay C, Hensel M (2008) Rational design of Salmonella recombinant vaccines. Int J Med Microbiol 298:87-98

Chumakov K, Ehrenfeld E, Wimmer E, Agol VI (2007) Vaccination against polio should not be stopped. Nat Rev Microbiol 5:952-958

Cicin-Sain L, Brune W, Bubic I, Jonjic S, Koszinowski UH (2003) Vaccination of mice with bacteria carrying a cloned herpesvirus genome reconstituted in vivo. J Virol 77:8249-8255

Coley WB (1893) The treatment of malignant tumors by repeated inoculations of erysipelas. With a report of ten original cases 1893. Clin Orthop Relat Res, 3-11

Collins PL, Mink MA, Stec DS (1991) Rescue of synthetic analogs of respiratory syncytial virus genomic RNA and effect of truncations and mutations on the expression of a foreign reporter gene. Proc Natl Acad Sci USA 88:9663-9667

Collins PL, Mink MA, Hill MG III, Camargo E, Grosfeld H, Stec DS (1993) Rescue of a 7502nucleotide (49.3\% of full-length) synthetic analog of respiratory syncytial virus genomic RNA. Virology 195:252-256

Conzelmann KK, Schnell M (1994) Rescue of synthetic genomic RNA analogs of rabies virus by plasmid-encoded proteins. J Virol 68:713-719

Cottingham MG, Andersen RF, Spencer AJ, Saurya S, Furze J, Hill AV, Gilbert SC (2008) Recombination-mediated genetic engineering of a bacterial artificial chromosome clone of modified vaccinia virus Ankara (MVA). PLoS One 3:e1638

Courvalin P, Goussard S, Grillot-Courvalin C (1995) Gene transfer from bacteria to mammalian cells. C R Acad Sci III 318:1207-1212

Covone MG, Brocchi M, Palla E, da Dias SW, Rappuoli R, Galeotti CL (1998) Levels of expression and immunogenicity of attenuated Salmonella enterica serovar typhimurium strains expressing Escherichia coli mutant heat-labile enterotoxin. Infect Immun 66:224-231

CR Health Net (2011) Clinical trials news feeds and updates. BioDrugs

Curtiss R III (1978) Biological containment and cloning vector transmissibility. J Infect Dis 137:668-675

Curtiss R III (2002) Bacterial infectious disease control by vaccine development. J Clin Invest 110:1061-1066

Curtiss R III, Galan JE, Nakayama K, Kelly SM (1990) Stabilization of recombinant avirulent vaccine strains in vivo. Res Microbiol 141:797-805

Curtiss R III, Wanda SY, Gunn BM, Zhang X, Tinge SA, Ananthnarayan V, Mo H, Wang S, Kong W (2009) Salmonella enterica serovar typhimurium strains with regulated delayed attenuation in vivo. Infect Immun 77:1071-1082

Curtiss R III, Xin W, Li Y, Kong W, Wanda SY, Gunn B, Wang S (2010) New technologies in using recombinant attenuated Salmonella vaccine vectors. Crit Rev Immunol 30:255-270

Daniel MD, Kirchhoff F, Czajak SC, Sehgal PK, Desrosiers RC (1992) Protective effects of a live attenuated SIV vaccine with a deletion in the nef gene. Science 258:1938-1941 
Darji A, Guzman CA, Gerstel B, Wachholz P, Timmis KN, Wehland J, Chakraborty T, Weiss S (1997) Oral somatic transgene vaccination using attenuated S. typhimurium. Cell 91:765-775

Daudel D, Weidinger G, Spreng S (2007) Use of attenuated bacteria as delivery vectors for DNA vaccines. Expert Rev Vaccines 6:97-110

de Vries RD, Stittelaar KJ, Osterhaus AD, de Swart RL (2008) Measles vaccination: new strategies and formulations. Expert Rev Vaccines 7:1215-1223

del Valle JR, Devaux P, Hodge G, Wegner NJ, McChesney MB, Cattaneo R (2007) A vectored measles virus induces hepatitis $\mathrm{B}$ surface antigen antibodies while protecting macaques against measles virus challenge. J Virol 81:10597-10605

Despres P, Combredet C, Frenkiel MP, Lorin C, Brahic M, Tangy F (2005) Live measles vaccine expressing the secreted form of the West Nile virus envelope glycoprotein protects against West Nile virus encephalitis. J Infect Dis 191:207-214

Dietrich G, Bubert A, Gentschev I, Sokolovic Z, Simm A, Catic A, Kaufmann SH, Hess J, Szalay AA, Goebel W (1998) Delivery of antigen-encoding plasmid DNA into the cytosol of macrophages by attenuated suicide Listeria monocytogenes. Nat Biotechnol 16:181-185

Dietrich G, Griot-Wenk M, Metcalfe IC, Lang AB, Viret JF (2003) Experience with registered mucosal vaccines. Vaccine 21:678-683

Domi A, Moss B (2002) Cloning the vaccinia virus genome as a bacterial artificial chromosome in Escherichia coli and recovery of infectious virus in mammalian cells. Proc Natl Acad Sci USA 99:12415-12420

Draper SJ, Heeney JL (2010) Viruses as vaccine vectors for infectious diseases and cancer. Nat Rev Microbiol 8:62-73

Drexler I, Heller K, Wahren B, Erfle V, Sutter G (1998) Highly attenuated modified vaccinia virus Ankara replicates in baby hamster kidney cells, a potential host for virus propagation, but not in various human transformed and primary cells. J Gen Virol 79(Pt 2):347-352

Ehrenfeld E, Modlin J, Chumakov K (2009) Future of polio vaccines. Expert Rev Vaccines 8:899-905

Fan H, Kumar M, La Ragione R, Woodward M (2004) Avian E. coli vaccine for the protection against colibacillosis. WO/2004/103402. 2004. WIPO

Fink SL, Cookson BT (2007) Pyroptosis and host cell death responses during Salmonella infection. Cell Microbiol 9:2562-2570

Fitzgerald DW, Janes H, Robertson M, Coombs R, Frank I, Gilbert P, Loufty M, Mehrotra D, Duerr A (2011) An Ad5-vectored HIV-1 vaccine elicits cell-mediated immunity but does not affect disease progression in HIV-1-infected male subjects: results from a randomized placebocontrolled trial (the Step study). J Infect Dis 203:765-772

Fraenkel-Conrat H, Mecham DK (1949) The reaction of formaldehyde with proteins; demonstration of intermolecular cross-linking by means of osmotic pressure measurements. J Biol Chem 177:477-486

Frey J (2007) Biological safety concepts of genetically modified live bacterial vaccines. Vaccine 25:5598-5605

Fu W, Chu L, Han X, Liu X, Ren D (2008a) Synergistic antitumoral effects of human telomerase reverse transcriptase-mediated dual-apoptosis-related gene vector delivered by orally attenuated Salmonella enterica Serovar Typhimurium in murine tumor models. J Gene Med 10:690-701

Fu W, Lan H, Li S, Han X, Gao T, Ren D (2008b) Synergistic antitumor efficacy of suicide/ePNP gene and 6-methylpurine 2'-deoxyriboside via Salmonella against murine tumors. Cancer Gene Ther 15:474-484

Fu W, Lan H, Liang S, Gao T, Ren D (2008c) Suicide gene/prodrug therapy using salmonellamediated delivery of Escherichia coli purine nucleoside phosphorylase gene and 6-methoxypurine $2^{\prime}$-deoxyriboside in murine mammary carcinoma 4 T1 model. Cancer Sci 99:1172-1179

Galen JE, Levine MM (2001) Can a 'flawless' live vector vaccine strain be engineered? Trends Microbiol 9:372-376 
Galen JE, Nair J, Wang JY, Wasserman SS, Tanner MK, Sztein MB, Levine MM (1999) Optimization of plasmid maintenance in the attenuated live vector vaccine strain Salmonella typhi CVD 908-htrA. Infect Immun 67:6424-6433

Galen JE, Pasetti MF, Tennant S, Ruiz-Olvera P, Sztein MB, Levine MM (2009) Salmonella enterica serovar Typhi live vector vaccines finally come of age. Immunol Cell Biol 87:400-412

Gaynor RB, Berk AJ (1983) Cis-acting induction of adenovirus transcription. Cell 33:683-693

Gentschev I, Dietrich G, Goebel W (2002) The E. coli alpha-hemolysin secretion system and its use in vaccine development. Trends Microbiol 10:39-45

Germanier R, Fürer E (1975) Isolation and characterization of Gal E mutant Ty 21a of Salmonella typhi: a candidate strain for a live, oral typhoid vaccine. J Infect Dis 131:553-558

Germanier R, Fürer E (1983) Characteristics of the attenuated oral vaccine strain "S. typhi" Ty 21a. Dev Biol Stand 53:3-7

GlaxoSmithKline (2011) Cervarix-product description

Goepfert PA, Elizaga ML, Sato A, Qin L, Cardinali M, Hay CM, Hural J, DeRosa SC, DeFawe OD, Tomaras GD, Montefiori DC, Xu Y, Lai L, Kalams SA, Baden LR, Frey SE, Blattner WA, Wyatt LS, Moss B, Robinson HL (2011) Phase 1 safety and immunogenicity testing of DNA and recombinant modified vaccinia Ankara vaccines expressing HIV-1 virus-like particles. J Infect Dis 203:610-619

Gomez CE, Najera JL, Domingo-Gil E, Ochoa-Callejero L, Gonzalez-Aseguinolaza G, Esteban M (2007) Virus distribution of the attenuated MVA and NYVAC poxvirus strains in mice. J Gen Virol 88:2473-2478

Gomez CE, Najera JL, Krupa M, Perdiguero B, Esteban M (2011) MVA and NYVAC as vaccines against emergent infectious diseases and cancer. Curr Gene Ther 11:189-217

Gonzalo-Asensio J, Mostowy S, Harders-Westerveen J, Huygen K, Hernandez-Pando R, Thole J, Behr M, Gicquel B, Martin C (2008) PhoP: a missing piece in the intricate puzzle of Mycobacterium tuberculosis virulence. PLoS One 3:3496

Govorkova EA, Murti G, Meignier B, de Taisne C, Webster RG (1996) African green monkey kidney (Vero) cells provide an alternative host cell system for influenza A and B viruses. J Virol 70:5519-5524

Gregersen JP, Schmitt HJ, Trusheim H, Broker M (2011) Safety of MDCK cell culture-based influenza vaccines. Future Microbiol 6:143-152

Griffin AJ, McSorley SJ (2011) Generation of Salmonella-specific Th1 cells requires sustained antigen stimulation. Vaccine 29:2697-2704

Griffin DE, Pan CH (2009) Measles: old vaccines, new vaccines. Curr Top Microbiol Immunol 330:191-212

Guan L, Mu W, Champeimont J, Wang Q, Wu H, Xiao J, Lubitz W, Zhang Y, Liu Q (2011) Ironregulated lysis of recombinant Escherichia coli in host releases protective antigen and confers biological containment. Infect Immun 79:2608-2618

Guerra S, Najera JL, Gonzalez JM, Lopez-Fernandez LA, Climent N, Gatell JM, Gallart T, Esteban M (2007) Distinct gene expression profiling after infection of immature human monocyte-derived dendritic cells by the attenuated poxvirus vectors MVA and NYVAC. J Virol 81:8707-8721

Gunn GR, Zubair A, Peters C, Pan ZK, Wu TC, Paterson Y (2001) Two Listeria monocytogenes vaccine vectors that express different molecular forms of human papilloma virus-16 (HPV-16) E7 induce qualitatively different $\mathrm{T}$ cell immunity that correlates with their ability to induce regression of established tumors immortalized by HPV-16. J Immunol 167:6471-6479

Guzman LM, Belin D, Carson MJ, Beckwith J (1995) Tight regulation, modulation, and high-level expression by vectors containing the arabinose PBAD promoter. J Bacteriol 177:4121-4130

Hangartner L (1997) Development of measles virus as a vector: expression of green fluorescent protein from different loci. Vaccine. University of Zurich, Zurich, Switzerland

Hansen SG, Ford JC, Lewis MS, Ventura AB, Hughes CM, Coyne-Johnson L, Whizin N, Oswald K, Shoemaker R, Swanson T, Legasse AW, Chiuchiolo MJ, Parks CL, Axthelm MK, Nelson JA, 
Jarvis MA, Piatak M Jr, Lifson JD, Picker LJ (2011) Profound early control of highly pathogenic SIV by an effector memory T-cell vaccine. Nature 473:523-527

Hayashi K, Zhao M, Yamauchi K, Yamamoto N, Tsuchiya H, Tomita K, Hoffman RM (2009a) Cancer metastasis directly eradicated by targeted therapy with a modified Salmonella typhimurium. J Cell Biochem 106:992-998

Hayashi K, Zhao M, Yamauchi K, Yamamoto N, Tsuchiya H, Tomita K, Kishimoto H, Bouvet M, Hoffman RM (2009b) Systemic targeting of primary bone tumor and lung metastasis of highgrade osteosarcoma in nude mice with a tumor-selective strain of Salmonella typhimurium. Cell Cycle 8:870-875

Heimann DM, Rosenberg SA (2003) Continuous intravenous administration of live genetically modified salmonella typhimurium in patients with metastatic melanoma. J Immunother 26:179-180

Higginson D, Theodoratou E, Nair H, Huda T, Zgaga L, Jadhav SS, Omer SB, Rudan I, Campbell $\mathrm{H}$ (2011) An evaluation of respiratory administration of measles vaccine for prevention of acute lower respiratory infections in children. BMC Public Health 11(Suppl 3):S31

Hohmann EL, Oletta CA, Loomis WP, Miller SI (1995) Macrophage-inducible expression of a model antigen in Salmonella typhimurium enhances immunogenicity. Proc Natl Acad Sci USA 92:2904-2908

Hoiseth SK, Stocker BA (1981) Aromatic-dependent Salmonella typhimurium are non-virulent and effective as live vaccines. Nature 291:238-239

Homchampa P, Strugnell RA, Adler B (1992) Molecular analysis of the aroA gene of Pasteurella multocida and vaccine potential of a constructed aroA mutant. Mol Microbiol 6:3585-3593

Hu AY, Tseng YF, Weng TC, Liao CC, Wu J, Chou AH, Chao HJ, Gu A, Chen J, Lin SC, Hsiao $\mathrm{CH}, \mathrm{Wu}$ SC, Chong P (2011) Production of inactivated influenza H5N1 vaccines from MDCK cells in serum-free medium. PLoS One 6:14578

Hueck CJ (1998) Type III protein secretion systems in bacterial pathogens of animals and plants. Microbiol Mol Biol Rev 62:379-433

Hunter Z, Tumban E, Dziduszko A, Chackerian B (2011) Aerosol delivery of virus-like particles to the genital tract induces local and systemic antibody responses. Vaccine 29:4584-4592

Jacobs AA, Goovaerts D, Nuijten PJ, Theelen RP, Hartford OM, Foster TJ (2000) Investigations towards an efficacious and safe strangles vaccine: submucosal vaccination with a live attenuated Streptococcus equi. Vet Rec 147:563-567

Jain V, Mekalanos JJ (2000) Use of lambda phage S and R gene products in an inducible lysis system for Vibrio cholerae- and Salmonella enterica serovar typhimurium-based DNA vaccine delivery systems. Infect Immun 68:986-989

Jalava K, Eko FO, Riedmann E, Lubitz W (2003) Bacterial ghosts as carrier and targeting systems for mucosal antigen delivery. Expert Rev Vaccines 2:45-51

Kastenmuller W, Gasteiger G, Stross L, Busch DH, Drexler I (2009) Cutting edge: mucosal application of a lyophilized viral vector vaccine confers systemic and protective immunity toward intracellular pathogens. J Immunol 182:2573-2577

Kaufman HE (2011) Adenovirus advances: new diagnostic and therapeutic options. Curr Opin Ophthalmol 22:290-293

Kaufmann SH (2007) The contribution of immunology to the rational design of novel antibacterial vaccines. Nat Rev Microbiol 5:491-504

Kaufmann SH, Hussey G, Lambert PH (2010) New vaccines for tuberculosis. Lancet 375:2110-2119

Kelly E, Russell SJ (2007) History of oncolytic viruses: genesis to genetic engineering. Mol Ther 15:651-659

Kenner J, Cameron F, Empig C, Jobes DV, Gurwith M (2006) LC16m8: an attenuated smallpox vaccine. Vaccine 24:7009-7022

Kimura H, Zhang L, Zhao M, Hayashi K, Tsuchiya H, Tomita K, Bouvet M, Wessels J, Hoffman RM (2010) Targeted therapy of spinal cord glioma with a genetically modified Salmonella typhimurium. Cell Prolif 43:41-48 
Kindsmuller K, Wagner R (2011) Synthetic biology: Impact on the design of innovative vaccines. Hum Vaccin 7:658-662

King I, Bermudes D, Lin S, Belcourt M, Pike J, Troy K, Le T, Ittensohn M, Mao J, Lang W, Runyan JD, Luo X, Li Z, Zheng LM (2002) Tumor-targeted salmonella expressing cytosine deaminase as an anticancer agent. Hum Gene Ther 13:1225-1233

Kirn DH (2006) The end of the beginning: oncolytic virotherapy achieves clinical proof-ofconcept. Mol Ther 13:237-238

Kirnbauer R, Booy F, Cheng N, Lowy DR, Schiller JT (1992) Papillomavirus L1 major capsid protein self-assembles into virus-like particles that are highly immunogenic. Proc Natl Acad Sci USA 89:12180-12184

Kochi SK, Killeen KP, Ryan US (2003) Advances in the development of bacterial vector technology. Expert Rev Vaccines 2:31-43

Kong W, Wanda SY, Zhang X, Bollen W, Tinge SA, Roland KL, Curtiss R III (2008) Regulated programmed lysis of recombinant Salmonella in host tissues to release protective antigens and confer biological containment. Proc Natl Acad Sci USA 105:9361-9366

Kost TA, Condreay JP (1999) Recombinant baculoviruses as expression vectors for insect and mammalian cells. Curr Opin Biotechnol 10:428-433

Kotton CN, Hohmann EL (2004) Enteric pathogens as vaccine vectors for foreign antigen delivery. Infect Immun 72:5535-5547

Kramer U, Rizos K, Apfel H, Autenrieth IB, Lattemann CT (2003) Autodisplay: development of an efficacious system for surface display of antigenic determinants in Salmonella vaccine strains. Infect Immun 71:1944-1952

Kreijtz JH, Osterhaus AD, Rimmelzwaan GF (2009) Vaccination strategies and vaccine formulations for epidemic and pandemic influenza control. Hum Vaccin 5:126-135

Kunik T, Tzfira T, Kapulnik Y, Gafni Y, Dingwall C, Citovsky V (2001) Genetic transformation of HeLa cells by Agrobacterium. Proc Natl Acad Sci USA 98:1871-1876

Kwon YM, Cox MM, Calhoun LN (2007) Salmonella-based vaccines for infectious diseases. Expert Rev Vaccines 6:147-152

Lee CH, Wu CL, Shiau AL (2004) Endostatin gene therapy delivered by Salmonella choleraesuis in murine tumor models. J Gene Med 6:1382-1393

Lee CH, Wu CL, Shiau AL (2005) Systemic administration of attenuated Salmonella choleraesuis carrying thrombospondin-1 gene leads to tumor-specific transgene expression, delayed tumor growth and prolonged survival in the murine melanoma model. Cancer Gene Ther 12:175-184

Legrand N, Ploss A, Balling R, Becker PD, Borsotti C, Brezillon N, Debarry J, de Jong Y, Deng H, Di Santo JP, Eisenbarth S, Eynon E, Flavell RA, Guzman CA, Huntington ND, Kremsdorf D, Manns MP, Manz MG, Mention JJ, Ott M, Rathinam C, Rice CM, Rongvaux A, Stevens S, Spits H, Strick-Marchand H, Takizawa H, van Lent AU, Wang C, Weijer K, Willinger T, Ziegler P (2009) Humanized mice for modeling human infectious disease: challenges, progress, and outlook. Cell Host Microbe 6:5-9

Lehmann MH, Kastenmuller W, Kandemir JD, Brandt F, Suezer Y, Sutter G (2009) Modified vaccinia virus ankara triggers chemotaxis of monocytes and early respiratory immigration of leukocytes by induction of CCL2 expression. J Virol 83:2540-2552

Leschner S, Weiss S (2010) Salmonella-allies in the fight against cancer. J Mol Med 88:763-773

Leschner S, Westphal K, Dietrich N, Viegas N, Jablonska J, Lyszkiewicz M, Lienenklaus S, Falk W, Gekara N, Loessner H, Weiss S (2009) Tumor invasion of Salmonella enterica serovar Typhimurium is accompanied by strong hemorrhage promoted by TNF-alpha. PLoS One 4: e6692

Leschner S, Deyneko IV, Lienenklaus S, Wolf K, Bloecker H, Bumann D, Loessner H, Weiss S, (2011) Identification of tumor-specific Salmonella Typhimurium promoters and their regulatory logic. Nucleic Acids Res. Epub.

Levine MM, Kaper JB (1993) Live oral vaccines against cholera: an update. Vaccine 11:207-212

Li Q, Cao C, Chackerian B, Schiller J, Gordon M, Ugen KE, Morgan D (2004) Overcoming antigen masking of anti-amyloidbeta antibodies reveals breaking of $\mathrm{B}$ cell tolerance by viruslike particles in amyloidbeta immunized amyloid precursor protein transgenic mice. BMC Neurosci 5:21 
Liao D, Luo Y, Markowitz D, Xiang R, Reisfeld RA (2009) Cancer associated fibroblasts promote tumor growth and metastasis by modulating the tumor immune microenvironment in a $4 \mathrm{~T} 1$ murine breast cancer model. PLoS One 4:e7965

Linde K, Keller H, Ezold R, Blatz R, Gericke B, Koch H, Kittlick M, Schmidt S (1974) Live vaccines against infections with Enterobacteriaceae. Problems of selection of attenuated mutants and their genetic stability. Acta Microbiol Acad Sci Hung 21:11-27

Liniger M, Zuniga A, Tamin A, Azzouz-Morin TN, Knuchel M, Marty RR, Wiegand M, Weibel S, Kelvin D, Rota PA, Naim HY (2008) Induction of neutralising antibodies and cellular immune responses against SARS coronavirus by recombinant measles viruses. Vaccine 26:2164-2174

Loeffler M, Le'Negrate G, Krajewska M, Reed JC (2007) Attenuated Salmonella engineered to produce human cytokine LIGHT inhibit tumor growth. Proc Natl Acad Sci USA 104:12879-12883

Loeffler M, Le'Negrate G, Krajewska M, Reed JC (2008a) IL-18-producing Salmonella inhibit tumor growth. Cancer Gene Ther 15:787-794

Loeffler M, Le'Negrate G, Krajewska M, Reed JC (2008b) Inhibition of tumor growth using salmonella expressing Fas ligand. J Natl Cancer Inst 100:1113-1116

Loeffler M, Le'Negrate G, Krajewska M, Reed JC (2009) Salmonella typhimurium engineered to produce CCL21 inhibit tumor growth. Cancer Immunol Immunother 58:769-775

Loessner H, Weiss S (2004) Bacteria-mediated DNA transfer in gene therapy and vaccination. Expert Opin Biol Ther 4:157-168

Loessner H, Weiss S (2007) In vivo remote control of bacterial vectors for prophylaxis and therapy. In: Sleator R, Hill C (eds) Patho-biotechnology. LandesBioscience/Eurekah, Austin, Texas

Loessner H, Endmann A, Rohde M, Curtiss R III, Weiss S (2006) Differential effect of auxotrophies on the release of macromolecules by Salmonella enterica vaccine strains. FEMS Microbiol Lett 265:81-88

Loessner H, Endmann A, Leschner S, Westphal K, Rohde M, Miloud T, Hammerling G, Neuhaus K, Weiss S (2007) Remote control of tumour-targeted Salmonella enterica serovar Typhimurium by the use of L-arabinose as inducer of bacterial gene expression in vivo. Cell Microbiol 9:1529-1537

Loessner H, Endmann A, Leschner S, Bauer H, Zelmer A, zur Lage S, Westphal K, Weiss S (2008) Improving live attenuated bacterial carriers for vaccination and therapy. Int $\mathrm{J}$ Med Microbiol 298:21-26

Loessner H, Leschner S, Endmann A, Westphal K, Wolf K, Kochruebe K, Miloud T, Altenbuchner J, Weiss S (2009) Drug-inducible remote control of gene expression by probiotic Escherichia coli Nissle 1917 in intestine, tumor and gall bladder of mice. Microbes Infect 11:1097-1105

Lorin C, Mollet L, Delebecque F, Combredet C, Hurtrel B, Charneau P, Brahic M, Tangy F (2004) A single injection of recombinant measles virus vaccines expressing human immunodeficiency virus (HIV) type 1 clade B envelope glycoproteins induces neutralizing antibodies and cellular immune responses to HIV. J Virol 78:146-157

Low KB, Ittensohn M, Le T, Platt J, Sodi S, Amoss M, Ash O, Carmichael E, Chakraborty A, Fischer J, Lin SL, Luo X, Miller SI, Zheng L, King I, Pawelek JM, Bermudes D (1999) Lipid A mutant Salmonella with suppressed virulence and TNFalpha induction retain tumortargeting in vivo [In Process Citation]. Nat Biotechnol 17:37-41

Luo Y, Zhou H, Mizutani M, Mizutani N, Liu C, Xiang R, Reisfeld RA (2005) A DNA vaccine targeting Fos-related antigen 1 enhanced by IL-18 induces long-lived T-cell memory against tumor recurrence. Cancer Res 65:3419-3427

Luo Y, Markowitz D, Xiang R, Zhou H, Reisfeld RA (2007) FLK-1-based minigene vaccines induce $\mathrm{T}$ cell-mediated suppression of angiogenesis and tumor protective immunity in syngeneic BALB/c mice. Vaccine 25:1409-1415

Maas A, Jacobsen ID, Meens J, Gerlach GF (2006) Use of an Actinobacillus pleuropneumoniae multiple mutant as a vaccine that allows differentiation of vaccinated and infected animals. Infect Immun 74:4124-4132 
Maciag PC, Radulovic S, Rothman J (2009) The first clinical use of a live-attenuated Listeria monocytogenes vaccine: a Phase I safety study of Lm-LLO-E7 in patients with advanced carcinoma of the cervix. Vaccine 27:3975-3983

Makela PH (2000) Vaccines, coming of age after 200 years. FEMS Microbiol Rev 24:9-20

Mansoor N, Scriba TJ, de Kock M, Tameris M, Abel B, Keyser A, Little F, Soares A, Gelderbloem S, Mlenjeni S, Denation L, Hawkridge A, Boom WH, Kaplan G, Hussey GD, Hanekom WA (2009) HIV-1 infection in infants severely impairs the immune response induced by Bacille Calmette-Guerin vaccine. J Infect Dis 199:982-990

Martin A, Staeheli P, Schneider U (2006) RNA polymerase II-controlled expression of antigenomic RNA enhances the rescue efficacies of two different members of the Mononegavirales independently of the site of viral genome replication. J Virol 80:5708-5715

Maurer J, Jose J, Meyer TF (1997) Autodisplay: one-component system for efficient surface display and release of soluble recombinant proteins from Escherichia coli. J Bacteriol 179:794-804

Mayr A, Hochstein-Mintzel V, Stickl H (1975) Passage history, properties and applicability of attenuated vaccinia virus strain MVA. Infection 3:6-14

Mayr A, Stickl H, Müller HK, Danner K, Singer H (1978) The smallpox vaccination strain MVA: marker, genetic structure, experience gained with the parenteral vaccination and behavior in organisms with a debilitated defence mechanism (author's transl). Zentralbl Bakteriol B $167: 375-390$

Mazumdar PMH (2003) Fundamental immunology, Chap 2: History of immunology. Lippincott Williams \& Wilkins, Philadelphia, pp 23-46

McAleer WJ, Buynak EB, Maigetter RZ, Wampler DE, Miller WJ, Hilleman MR (1984) Human hepatitis B vaccine from recombinant yeast. Nature 307:178-180

Meeusen EN, Walker J, Peters A, Pastoret PP, Jungersen G (2007) Current status of veterinary vaccines. Clin Microbiol Rev 20:489-510

Melcher A, Parato K, Rooney CM, Bell JC (2011) Thunder and lightning: immunotherapy and oncolytic viruses collide. Mol Ther 19:1008-1016

Merck\&CO (2011) I. Gardasil—product description

Metz B, Jiskoot W, Hennink WE, Crommelin DJ, Kersten GF (2003) Physicochemical and immunochemical techniques predict the quality of diphtheria toxoid vaccines. Vaccine 22:156-167

Meyer H, Sutter G, Mayr A (1991) Mapping of deletions in the genome of the highly attenuated vaccinia virus MVA and their influence on virulence. J Gen Virol 72(Pt 5):1031-1038

Meyer H, Steinbach G, Methner U (1993) Control of salmonella infections in animal herds-basis for a reduction of salmonella entries into food. Dtsch Tierarztl Wochenschr 100:292-295

Mooij P, Balla-Jhagjhoorsingh SS, Koopman G, Beenhakker N, van Haaften P, Baak I, Nieuwenhuis IG, Kondova I, Wagner R, Wolf H, Gomez CE, Najera JL, Jimenez V, Esteban M, Heeney JL (2008) Differential CD4+ versus CD8+ T-cell responses elicited by different poxvirus-based human immunodeficiency virus type 1 vaccine candidates provide comparable efficacies in primates. J Virol 82:2975-2988

Moreno M, Kramer MG, Yim L, Chabalgoity JA (2010) Salmonella as live trojan horse for vaccine development and cancer gene therapy. Curr Gene Ther 10:56-76

Muruve DA (2004) The innate immune response to adenovirus vectors. Hum Gene Ther 15:1157-1166

Nagakura C, Hayashi K, Zhao M, Yamauchi K, Yamamoto N, Tsuchiya H, Tomita K, Bouvet M, Hoffman RM (2009) Efficacy of a genetically-modified Salmonella typhimurium in an orthotopic human pancreatic cancer in nude mice. Anticancer Res 29:1873-1878

Najera JL, Gomez CE, Domingo-Gil E, Gherardi MM, Esteban M (2006) Cellular and biochemical differences between two attenuated poxvirus vaccine candidates (MVA and NYVAC) and role of the C7L gene. J Virol 80:6033-6047

Nemunaitis J, Cunningham C, Senzer N, Kuhn J, Cramm J, Litz C, Cavagnolo R, Cahill A, Clairmont C, Sznol M (2003) Pilot trial of genetically modified, attenuated Salmonella expressing the E. coli cytosine deaminase gene in refractory cancer patients. Cancer Gene Ther 10:737-744 
Nguyen VH, Kim HS, Ha JM, Hong Y, Choy HE, Min JJ (2010) Genetically engineered Salmonella typhimurium as an imageable therapeutic probe for cancer. Cancer Res 70:18-23

Niethammer AG, Xiang R, Becker JC, Wodrich H, Pertl U, Karsten G, Eliceiri BP, Reisfeld RA (2002) A DNA vaccine against VEGF receptor 2 prevents effective angiogenesis and inhibits tumor growth. Nat Med 8:1369-1375

Nikles D, Bach P, Boller K, Merten CA, Montrasio F, Heppner FL, Aguzzi A, Cichutek K, Kalinke U, Buchholz CJ (2005) Circumventing tolerance to the prion protein (PrP): vaccination with PrP-displaying retrovirus particles induces humoral immune responses against the native form of cellular PrP. J Virol 79:4033-4042

Ogawa M, Yoshimori T, Suzuki T, Sagara H, Mizushima N, Sasakawa C (2005) Escape of intracellular Shigella from autophagy. Science 307:727-731

Ohno S, Ono N, Seki F, Takeda M, Kura S, Tsuzuki T, Yanagi Y (2007) Measles virus infection of SLAM (CD150) knockin mice reproduces tropism and immunosuppression in human infection. J Virol 81:1650-1659

Pandey A, Singh N, Sambhara S, Mittal SK (2010) Egg-independent vaccine strategies for highly pathogenic H5N1 influenza viruses. Hum Vaccin 6:178-188

Panthel K, Meinel KM, Sevil Domenech VE, Trulzsch K, Russmann H (2008) Salmonella type IIImediated heterologous antigen delivery: a versatile oral vaccination strategy to induce cellular immunity against infectious agents and tumors. Int J Med Microbiol 298:99-103

Paran N, Sutter G (2009) Smallpox vaccines: New formulations and revised strategies for vaccination. Hum Vaccin 5:824-831

Paran N, Suezer Y, Lustig S, Israely T, Schwantes A, Melamed S, Katz L, Preuss T, Hanschmann KM, Kalinke U, Erez N, Levin R, Velan B, Lower J, Shafferman A, Sutter G (2009) Postexposure immunization with modified vaccinia virus Ankara or conventional Lister vaccine provides solid protection in a murine model of human smallpox. J Infect Dis 199:39-48

Pasteur L (1880) De l'attenuation du virus du choléra des poules. C R Acad Sci Paris 91:673-680

Pawelek JM, Low KB, Bermudes D (1997) Tumor-targeted Salmonella as a novel anticancer vector. Cancer Res 57:4537-4544

Poulet H, Minke J, Pardo MC, Juillard V, Nordgren B, Audonnet JC (2007) Development and registration of recombinant veterinary vaccines. The example of the canarypox vector platform. Vaccine 25:5606-5612

Previsani N, Lavanchy D (2002) Hepatitis B. WHO/CDS/CSR/LYO/2002.2: Hepatitis B

Randrianarison-Jewtoukoff V, Perricaudet M (1995) Recombinant adenoviruses as vaccines. Biologicals 23:145-157

Reisfeld RA, Niethammer AG, Luo Y, Xiang R (2004) DNA vaccines designed to inhibit tumor growth by suppression of angiogenesis. Int Arch Allergy Immunol 133:295-304

Rerks-Ngarm S, Brown AE, Khamboonruang C, Thongcharoen P, Kunasol P (2006) HIV/AIDS preventive vaccine 'prime-boost' phase III trial: foundations and initial lessons learned from Thailand. AIDS 20:1471-1479

Richards CA, Brown CE, Cogswell JP, Weiner MP (2000) The admid system: generation of recombinant adenoviruses by Tn7-mediated transposition in E. coli. Biotechniques 29:146-154

Royo JL, Becker PD, Camacho EM, Cebolla A, Link C, Santero E, Guzman CA (2007) In vivo gene regulation in Salmonella spp. by a salicylate-dependent control circuit. Nat Methods 4:937-942

Russmann H, Shams H, Poblete F, Fu Y, Galan JE, Donis RO (1998) Delivery of epitopes by the Salmonella type III secretion system for vaccine development. Science 281:565-568

Russmann H, Gerdemann U, Igwe EI, Panthel K, Heesemann J, Garbom S, Wolf-Watz H, Geginat G (2003) Attenuated Yersinia pseudotuberculosis carrier vaccine for simultaneous antigenspecific CD4 and CD8 T-cell induction. Infect Immun 71:3463-3472

Ryan RM, Green J, Williams PJ, Tazzyman S, Hunt S, Harmey JH, Kehoe SC, Lewis CE (2009) Bacterial delivery of a novel cytolysin to hypoxic areas of solid tumors. Gene Ther 16:329-339 
Saltzman DA, Heise CP, Hasz DE, Zebede M, Kelly SM, Curtiss R III, Leonard AS, Anderson PM (1996) Attenuated Salmonella typhimurium containing interleukin-2 decreases MC-38 hepatic metastases: a novel anti-tumor agent. Cancer Biother Radiopharm 11:145-153

Saltzman DA, Katsanis E, Heise CP, Hasz DE, Vigdorovich V, Kelly SM, Curtiss R III, Leonard AS, Anderson PM (1997) Antitumor mechanisms of attenuated Salmonella typhimurium containing the gene for human interleukin-2: a novel antitumor agent? J Pediatr Surg 32:301-306

Santi L, Huang Z, Mason H (2006) Virus-like particles production in green plants. Methods 40:66-76

Schaffner W (1980) Direct transfer of cloned genes from bacteria to mammalian cells. Proc Natl Acad Sci USA 77:2163-2167

Schmaljohn AL, McClain D (2011) Alphaviruses (Togaviridae) and Flaviviruses (Flaviviridae). In: Baron S (ed) Medical microbiology. University of Texas Medical Branch, Galveston

Schneider H, Spielhofer P, Kaelin K, Dotsch C, Radecke F, Sutter G, Billeter MA (1997) Rescue of measles virus using a replication-deficient vaccinia-T7 vector. J Virol Methods 64:57-64

Shahabi V, Reyes-Reyes M, Wallecha A, Rivera S, Paterson Y, Maciag P (2008) Development of a Listeria monocytogenes based vaccine against prostate cancer. Cancer Immunol Immunother 57:1301-1313

Sidhu MS, Chan J, Kaelin K, Spielhofer P, Radecke F, Schneider H, Masurekar M, Dowling PC, Billeter MA, Udem SA (1995) Rescue of synthetic measles virus minireplicons: measles genomic termini direct efficient expression and propagation of a reporter gene. Virology 208:800-807

Silva AJ, Benitez JA, Wu JH (2010) Attenuation of bacterial virulence by quorum sensingregulated lysis. J Biotechnol 150:22-30

Singh M, Cattaneo R, Billeter MA (1999) A recombinant measles virus expressing hepatitis B virus surface antigen induces humoral immune responses in genetically modified mice. J Virol 73:4823-4828

Sinkovics J, Horvath J (1993) New developments in the virus therapy of cancer: a historical review. Intervirology 36:193-214

Sizemore DR, Branstrom AA, Sadoff JC (1995) Attenuated Shigella as a DNA delivery vehicle for DNA-mediated immunization. Science 270:299-302

Song J, Willinger T, Rongvaux A, Eynon EE, Stevens S, Manz MG, Flavell RA, Galán JE (2010) A mouse model for the human pathogen Salmonella typhi. Cell Host Microbe 21: 369-376

Sorenson BS, Banton KL, Frykman NL, Leonard AS, Saltzman DA (2008a) Attenuated Salmonella typhimurium with IL-2 gene reduces pulmonary metastases in murine osteosarcoma. Clin Orthop Relat Res 466:1285-1291

Sorenson BS, Banton KL, Frykman NL, Leonard AS, Saltzman DA (2008b) Attenuated Salmonella typhimurium with interleukin 2 gene prevents the establishment of pulmonary metastases in a model of osteosarcoma. J Pediatr Surg 43:1153-1158

Staib C, Drexler I, Ohlmann M, Wintersperger S, Erfle V, Sutter G (2000) Transient host range selection for genetic engineering of modified vaccinia virus Ankara. Biotechniques 28(1137-6): 1148

Stratford R, McKelvie ND, Hughes NJ, Aldred E, Wiseman C, Curtis J, Bellaby T, Bentley M, Hindle Z, Brennan FR, Chatfield SN, Dougan G, Khan SA (2005) Optimization of Salmonella enterica serovar typhi DeltaaroC DeltassaV derivatives as vehicles for delivering heterologous antigens by chromosomal integration and in vivo inducible promoters. Infect Immun 73:362-368

Strebel P, Cochi S, Grabowsky M, Bilous J, Hersh BS, Okwo-Bele JM, Hoekstra E, Wright P, Katz S (2003) The unfinished measles immunization agenda. J Infect Dis 187(Suppl 1):S1-S7

Sutter G, Moss B (1992) Nonreplicating vaccinia vector efficiently expresses recombinant genes. Proc Natl Acad Sci USA 89:10847-10851 
Takeda M, Ohno S, Seki F, Hashimoto K, Miyajima N, Takeuchi K, Yanagi Y (2005) Efficient rescue of measles virus from cloned cDNA using SLAM-expressing Chinese hamster ovary cells. Virus Res 108:161-165

Tangy F, Naim HY (2005) Live attenuated measles vaccine as a potential multivalent pediatric vaccination vector. Viral Immunol 18:317-326

Tartaglia J, Perkus ME, Taylor J, Norton EK, Audonnet JC, Cox WI, Davis SW, van der Hoeven J, Meignier B, Riviere M (1992) NYVAC: a highly attenuated strain of vaccinia virus. Virology 188:217-232

Taylor J, Trimarchi C, Weinberg R, Languet B, Guillemin F, Desmettre P, Paoletti E (1991) Efficacy studies on a canarypox-rabies recombinant virus. Vaccine 9:190-193

Toso JF, Gill VJ, Hwu P, Marincola FM, Restifo NP, Schwartzentruber DJ, Sherry RM, Topalian SL, Yang JC, Stock F, Freezer LJ, Morton KE, Seipp C, Haworth L, Mavroukakis S, White D, MacDonald S, Mao J, Sznol M, Rosenberg SA (2002) Phase I study of the intravenous administration of attenuated Salmonella typhimurium to patients with metastatic melanoma. J Clin Oncol 20:142-152

Vaccari M, Poonam P, Franchini G (2010) Phase III HIV vaccine trial in Thailand: a step toward a protective vaccine for HIV. Expert Rev Vaccines 9:997-1005

Valdivia RH, Falkow S (1997) Fluorescence-based isolation of bacterial genes expressed within host cells. Science 277:2007-2011

Valenzuela P, Medina A, Rutter WJ, Ammerer G, Hall BD (1982) Synthesis and assembly of hepatitis B virus surface antigen particles in yeast. Nature 298:347-350

van Oirschot JT (2001) Present and future of veterinary viral vaccinology: a review. Vet Q 23:100-108

Vaughan LM, Smith PR, Foster TJ (1993) An aromatic-dependent mutant of the fish pathogen Aeromonas salmonicida is attenuated in fish and is effective as a live vaccine against the salmonid disease furunculosis. Infect Immun 61:2172-2181

Verma NK, Lindberg AA (1991) Construction of aromatic dependent Shigella flexneri 2a live vaccine candidate strains: deletion mutations in the aroA and the aroD genes. Vaccine 9:6-9

von Krempelhuber A, Vollmar J, Pokorny R, Rapp P, Wulff N, Petzold B, Handley A, Mateo L, Siersbol H, Kollaritsch H, Chaplin P (2010) A randomized, double-blind, dose-finding Phase II study to evaluate immunogenicity and safety of the third generation smallpox vaccine candidate IMVAMUNE. Vaccine 28:1209-1216

Waibler Z, Anzaghe M, Ludwig H, Akira S, Weiss S, Sutter G, Kalinke U (2007) Modified vaccinia virus Ankara induces Toll-like receptor-independent type I interferon responses. J Virol 81:12102-12110

Walpita P, Barr J, Sherman M, Basler CF, Wang L (2011) Vaccine potential of Nipah virus-like particles. PLoS One 6:e18437

Wang Z, Hangartner L, Cornu TI, Martin LR, Zuniga A, Billeter MA, Naim HY (2001) Recombinant measles viruses expressing heterologous antigens of mumps and simian immunodeficiency viruses. Vaccine 19:2329-2336

Waters VL (2001) Conjugation between bacterial and mammalian cells. Nat Genet 29:375-376

Wells JM, Mercenier A (2008) Mucosal delivery of therapeutic and prophylactic molecules using lactic acid bacteria. Nat Rev Microbiol 6:349-362

Westphal K, Leschner S, Jablonska J, Loessner H, Weiss S (2008) Containment of tumorcolonizing bacteria by host neutrophils. Cancer Res 68:2952-2960

WHO (2009) Weekly epidemiological record - Hepatitis B vaccines. Strategy paper 84[40], 405-420. World Health Organization

WHO publication (2008) Preparing for the Introduction of HPV Vaccine in the WHO European Region; Strategy paper

Wilck MB, Seaman MS, Baden LR, Walsh SR, Grandpre LE, Devoy C, Giri A, Kleinjan JA, Noble LC, Stevenson KE, Kim HT, Dolin R (2010) Safety and immunogenicity of modified vaccinia Ankara (ACAM3000): effect of dose and route of administration. J Infect Dis 201:1361-1370 
Wolff JA, Lederberg J (1994) An early history of gene transfer and therapy. Hum Gene Ther 5:469-480

Xiang R, Mizutani N, Luo Y, Chiodoni C, Zhou H, Mizutani M, Ba Y, Becker JC, Reisfeld RA (2005) A DNA vaccine targeting survivin combines apoptosis with suppression of angiogenesis in lung tumor eradication. Cancer Res 65:553-561

Xiang S, Fruehauf J, Li CJ (2006) Short hairpin RNA-expressing bacteria elicit RNA interference in mammals. Nat Biotechnol 24:697-702

Xin W, Wanda SY, Li Y, Wang S, Mo H, Curtiss R III (2008) Analysis of type II secretion of recombinant pneumococcal PspA and PspC in a Salmonella enterica serovar Typhimurium vaccine with regulated delayed antigen synthesis. Infect Immun 76:3241-3254

Yang N, Zhu X, Chen L, Li S, Ren D (2008) Oral administration of attenuated S. typhimurium carrying shRNA-expressing vectors as a cancer therapeutic. Cancer Biol Ther 7:145-151

Yoon WS, Choi WC, Sin JI, Park YK (2007) Antitumor therapeutic effects of Salmonella typhimurium containing Flt3 Ligand expression plasmids in melanoma-bearing mouse. Biotechnol Lett 29:511-516

Yu YA, Shabahang S, Timiryasova TM, Zhang Q, Beltz R, Gentschev I, Goebel W, Szalay AA (2004) Visualization of tumors and metastases in live animals with bacteria and vaccinia virus encoding light-emitting proteins. Nat Biotechnol 22:313-320

Zanotto C, Pozzi E, Pacchioni S, Volonte L, De Giuli MC, Radaelli A (2010) Canarypox and fowlpox viruses as recombinant vaccine vectors: a biological and immunological comparison. Antiviral Res 88:53-63

Zhang X, Wanda SY, Brenneman K, Kong W, Zhang X, Roland K, Curtiss R III (2011) Improving Salmonella vector with rec mutation to stabilize the DNA cargoes. BMC Microbiol 11:31

Zhao M, Yang M, Li XM, Jiang P, Baranov E, Li S, Xu M, Penman S, Hoffman RM (2005) Tumor-targeting bacterial therapy with amino acid auxotrophs of GFP-expressing Salmonella typhimurium. Proc Natl Acad Sci USA 102:755-760

Zhao M, Yang M, Ma H, Li X, Tan X, Li S, Yang Z, Hoffman RM (2006) Targeted therapy with a Salmonella typhimurium leucine-arginine auxotroph cures orthotopic human breast tumors in nude mice. Cancer Res 66:7647-7652

Zhao M, Geller J, Ma H, Yang M, Penman S, Hoffman RM (2007) Monotherapy with a tumortargeting mutant of Salmonella typhimurium cures orthotopic metastatic mouse models of human prostate cancer. Proc Natl Acad Sci USA 104:10170-10174

Zuniga A, Wang Z, Liniger M, Hangartner L, Caballero M, Pavlovic J, Wild P, Viret JF, Glueck R, Billeter MA, Naim HY (2007) Attenuated measles virus as a vaccine vector. Vaccine 25:2974-2983 